MAX MORITZ,

University

of California

Cooperative

Extension Wildfire

Specialist in the

Bren School of

Environmental

Science and

Management at UC

Santa Barbara;

VAN BUTSIC,

University

of California

Cooperative

Extension Assistant

Land-Use Specialist

in the Department

of Environmental

Science, Policy, and

Management at UC Berkeley

\section{Building to Coexist with Fire: Community Risk Reduction Measures for New Development in California}

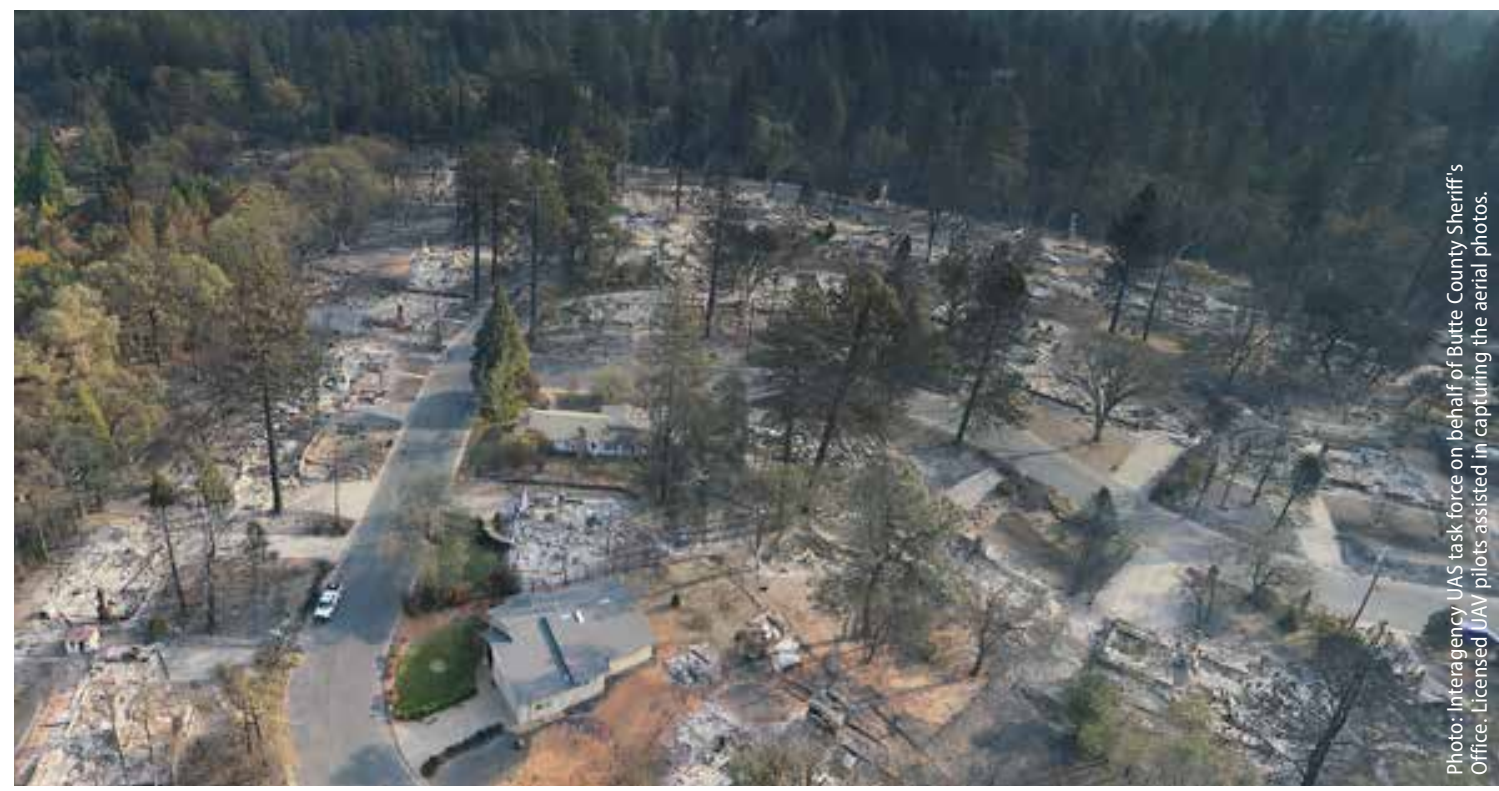

Drone imagery of a post-fire neighborhood in Paradise, California. The 2018 Camp Fire was the deadliest in California's modern history, destroying most of the towns of Concow and Paradise. To live on fire-prone landscapes, better guidance on where and how we build our communities is urgently needed.

\section{What matters most is how well you walk through the fire.}

Charles Bukowski, 1920-1994 inclusion of fire professionals in the planning process; the spatial placement of communities; how communities are laid out to minimize exposure; and key defensibility, ignition, and evacuation concerns. Examples are provided for each RRM, along with some consideration of challenges associated with their implementation. Our hope is that this guidance will be helpful for agency personnel involved in evaluating and approving future development in California. Because there is a pressing need for additional housing in California, communities must be built with design principles that make them safer to inhabit and less vulnerable to inevitable wildfires. 


\section{Traditional Neighborhood}

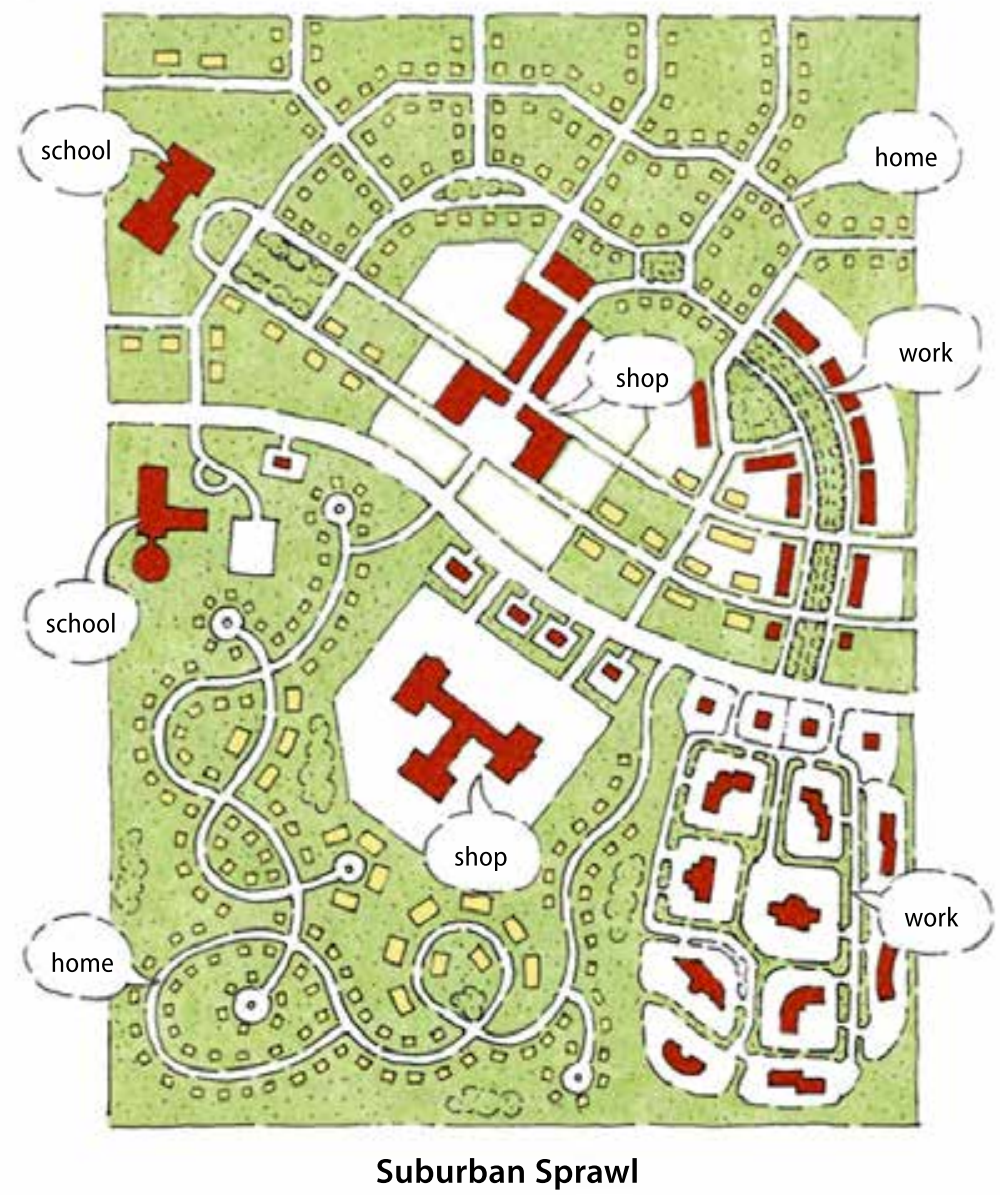

Figure 1. Neighborhood design strategies. Urban planning discussions often include pros and cons of different design layouts, such as the more walkable and mixed-use "traditional" pattern in which people live relatively close to shopping and workplaces; this is in contrast to a "sprawl" pattern that is designed for and dependent on automobile use. Community siting and design must increasingly integrate wildfire vulnerability more explicitly.

Source: DPZ CoDESIGN.

\section{INTRODUCTION AND BACKGROUND}

Protecting homes and lives from wildfire in the wildland-urban interface (WUI) requires smart design and management at multiple spatial scales. Planning considerations involved go well beyond the trade-offs associated with "traditional" and walkable neighborhood layout patterns versus car-dependent "sprawl" patterns (fig. 1). Even so, most advice aimed at mitigating wildfire danger in the WUI strongly emphasizes vegetation concerns over design and planning considerations (e.g., FEMA 2008; NACo 2010; Stein et al. 2013); this is because people can take strategic actions that mitigate hazards posed by dangerous types and amounts of fuels in the built environment. Such actions can effectively target fuels around structures, creating defensible space for firefighters, or reduce fuels at key locations in and around communities. But because the source of the hazard tends to grow back, fuels mitigation is nearly always an ongoing concern in the WUI.

For a variety of political and cultural reasons, structure ignition vulnerabilities in California's built environment have typically been addressed through building codes. Depending on where one lives in the state, building codes are determined to different degrees by the Fire Hazard Severity Zone maps produced by CAL FIRE and by State Responsibility Area designations. These codes require use of certain construction materials and methods to achieve a higher level of fire resistance for an individual home (that is, to reduce the structure's ignition potential). Additional regulations ensure minimum levels of road access and minimum water supplies for a neighborhood. After a community or subdivision has been developed, however, the responsibility to mitigate vulnerabilities in the built environment falls on homeowners themselves, whose resources for retrofitting structures are often limited. At that point the location of homes with respect to oncoming wildfires, or homes' spatial arrangement and exposure in a neighborhood, must be taken as a given. The safety of both inhabitants and those protecting neighborhoods can therefore be forever compromised. 
Comprehensive and practical guidance is crucial for urban design and land-use planning decisions on fire-prone landscapes because such decisions can have an enormous influence on the future likelihood of losses. Losses can include structures, the lives of both homeowners and firefighters, and the costs of fire suppression activities. A great deal has been learned about urban design and land use in the context of wildfire, and there are several ways they can play a key role in reducing community risk (e.g., Gross 2009; Blonski et al. 2010; Brzuszek et al. 2010; Buxton et al. 2011; Duerksen et al. 2011; Bihari et al. 2012; NFPA 2013; Gonzalez-Mathiesen and March 2014; Moritz et al. 2014; Opie et al. 2014; March and Rijal 2015; Hakes et al. 2017; Alexandre, Stewart, Mockrin et al. 2016; Alexandre, Stewart, Keuler et al. 2016; Headwaters Economics 2016; Syphard et al. 2017; Mowery et al. 2019). The goal of this document is to distill the most relevant scientific findings and lessons from practitioners into a guide for locating and designing new subdivisions on fire-prone landscapes. While legislators in California continue to seek ways to address wildfire challenges, the timely solutions highlighted here provide effective options that may go beyond legislative requirements.

Our synthesis spans roughly from the community to the neighborhood level (fig. 2), a scale at which few risk reduction measures have been codified in California. We focus on issues other than fuels clearance and road access (as specified in Alex et al. 2014) or building codes for individual structures (as dictated by Fire Hazard Severity Zones). Given California's pace of development and its increasing rate of home losses due to wildfire, guidance on how to design not just fire-safe homes but fire-safe neighborhoods is urgently needed.

\section{WUI Administration at Various Scales}

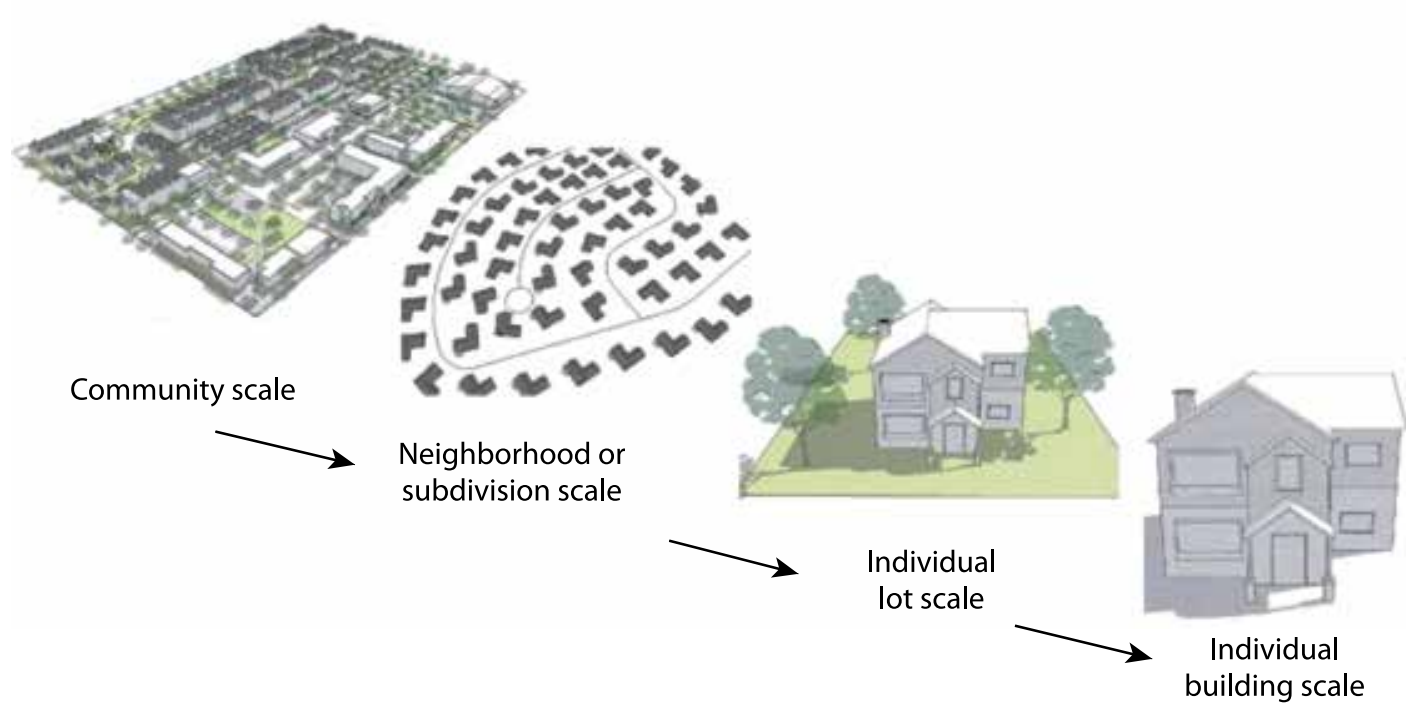

Figure 2. Regulatory scales in the WUI. Our synthesis focuses on the two coarsest scales, emphasizing the overall spatial location (community scale) and spatial layout (neighborhood/subdivision scale) of new developments on fire-prone landscapes.

Source: Duerksen et al. 2011. Courtesy National Fire Protection Association. 


\section{Data Gathering and Literature Review}

Our interactions with local and statewide personnel representing both planning agencies and fire agencies have revealed a need to document RRMs for the siting and design of communities. For example, though considerable professional experience generally informs the feedback that development proposals receive during the planning and review process, no codified or standardized guidance underpins this feedback - the nature of which varies widely across municipalities, even for very similar development proposals. The tragic fire losses of 2017 and 2018 have also highlighted the need for community-scale RRMs that accommodate extreme circumstances.

Along with agency personnel interactions, a synthesis of material from published literature-particularly for California and fire-prone parts of Australia-has suggested new guidance on RRMs for the location and layout of developments in fire-prone environments. An additional important resource is a new report from the American Planning Association (Mowery et al. 2019), which contains a comprehensive overview of fire-related concepts for planners, as well as guidance on improving the planning process in fire-prone environments. The set of RRMs presented here partially overlaps with recommendations in the American Planning Association report, but that report is "mustread" material for anyone interested in these issues.

Note that we consider this guide an early step in documenting community RRMs. The contents of this guide will need to be updated as new research findings emerge.

\section{Risk Reduction and Community Design}

In a generic sense, the risk of home losses and fatalities is a function of hazard (for example, probabilities of fire frequencies or flame lengths), exposure (including home locations), and vulnerability (ease of defense or potential for structure ignition). Over the long term, fire activity in a region can also be strongly influenced by development patterns themselves (Syphard et al. 2007; Butsic et al. 2015; Mann et al. 2016). Development proposals must therefore be evaluated according to how they will threaten (or protect) existing communities-but this consideration is often overlooked in the planning process.

Here we consider a set of community design elements important for wildfire risk reduction (Gonzalez-Mathiesen and March 2014; March and Rijal 2015), and we identify RRMs for the placement and design of subdivisions to reduce their exposure and vulnerability. Some elements address the locations where development should be concentrated on the landscape, while others are concerned with the spatial layout of communities. During the most extreme wildfire events, some RRMs may be overwhelmed, making safe evacuation impossible; one element therefore addresses creating local public refuges of last resort. Adequate water supplies and their use in extreme situations are also addressed.

The goals of the RRMs identified here are often to increase distance from the source of hazard or to facilitate defense of a subdivision during a wildfire. Both of these strategies are recognized as important in protecting lives and homes, so they must be included in comprehensive planning processes (for example, FEMA 2013). In relatively rare but noteworthy cases, planning ordinances do incorporate measures such as avoiding a landscape's most hazardous portions in the first place (fig. 3). Such examples provide a valuable precedent for making challenging decisions in urban design and land-use planning. In any event, it is crucial that such issues be addressed in the planning and design stage, especially if they have yet to be regulated through accepted development codes or ordinances.

\section{Trade-offs and Social Values}

Many areas of California face a housing crisis due to a lack of affordable residential units. California has also experienced rising home losses in recent years, as fires have devastated portions of the ever-expanding WUI. The RRMs described here are not intended to constrain housing supplies even further in the future. How can California thread the needle to provide more housing-sometimes on landscapes with elevated fire hazard-while also reducing exposure and overall risk? 
includes sites on and along the beaches, bluffs, tidally influenced water bodies and areas potentially subject to inundation given topography and proximity to the ocean.

Dev Std LU-3: Fire Protection. Development shall be sited to minimize exposure to fire hazards and reduce the need for grading, fuel modification (including thinning of vegetation and limbing of trees), and clearance of native vegetation to the maximum extent feasible. Building sites should be located in areas of a parcel's lowest fire hazard, and should minimize the need for long and/or steep access roads and/or driveways.

Dev Std LU-4: Radon. Development proposed on Rincon Formation soils or within state-mapped elevated radon hazard zones shall be avoided to the extent feasible; if infeasible, development shall be

Figure 3. Siting requirements in the land-use development standards described in Santa Barbara County's Gaviota Coast Plan (SBCPDD 2016).

The goal is not to reduce housing growth but instead to encourage smarter design and construction that allow coexistence with inevitable wildfires. California should increase its housing stock by prioritizing in-fill and redevelopment of existing urban areas, such as underutilized downtown space and vacant malls. Because most urbanized areas are at relatively low risk of wildfire-related losses, and because in-fill and redevelopment consume low amounts of natural or agriculturally productive lands, such a strategy offers many benefits to society. A number of smart-growth principles can be used to transform distressed urban areas into healthy and green communities (see, for example, Duany et al. 2010). Another priority is to "repair" many existing suburban communities (Tachieva 2010), simultaneously making them safer and more livable. Because increased housing density has historically been associated with lower risk of home losses (Syphard et al. 2019), creating more residential units in existing suburban areas should be a goal. Lastly, where new development occurs on or near flammable landscapes, priority should be given to clustered communities with higher densities, built according to smart-growth principles and
RRMs as described here. The result for society should be increased housing, development that is less vulnerable to fire, and communities that are greener and more livable (for example, walkable neighborhoods that preserve open space or farmlands).

Near the end of this document, for completeness, a short series of "competing considerations" is discussed. Lowering fire risk often involves trade-offs that can compromise environmental values or other social values. Native vegetation and biological resources in general are emphasized as competing considerations, but other potential conflicts may still need to be addressed. An appendix section contains a glossary of terms and material highlighting additional examples of RRMs identified here.

\section{DESIGN CONTEXTS AND RISK REDUCTION MEASURES}

In the following pages, we discuss four design contexts-landscape setting, separation from wildfire source, density management, and infrastructure concerns-and present a series of RRMs that correspond to them (table 1). 
Table 1. Community RRMs for the location and layout of new subdivisions on fire-prone landscapes

\begin{tabular}{|c|c|c|c|}
\hline Design context & RRM & Scale & Goal \\
\hline landscape setting & $\begin{array}{l}\text { - engage in strategic } \\
\text { planning much earlier } \\
\text { - use hazard maps } \\
\text { - use major landscape } \\
\text { features }\end{array}$ & $\begin{array}{l}\text { - community and } \\
\text { subdivision } \\
\text { - community location } \\
\text { - community location }\end{array}$ & $\begin{array}{l}\text { - address fire risk before } \\
\text { other considerations } \\
\text { finalized } \\
\text { - concentrate in least } \\
\text { hazardous areas } \\
\text { - buffer against } \\
\text { oncoming wildfires }\end{array}$ \\
\hline $\begin{array}{l}\text { separation from } \\
\text { wildfire source }\end{array}$ & $\begin{array}{l}\text { - use nonflammable } \\
\text { amenities in design } \\
\text { - employ safe setbacks } \\
\text { on slopes } \\
\text { - concentrate on inner } \\
\text { side of roadways }\end{array}$ & $\begin{array}{l}\text { - } \text { subdivision layout } \\
\text { - } \text { subdivision layout } \\
\text { - } \text { subdivision layout }\end{array}$ & $\begin{array}{l}\text { - maximize defensible } \\
\text { space } \\
\text { - maximize defensible } \\
\text { space } \\
\text { - maximize defensible } \\
\text { space }\end{array}$ \\
\hline density management & cluster with other homes & subdivision layout & $\begin{array}{l}\text { reduce collective } \\
\text { exposure }\end{array}$ \\
\hline $\begin{array}{l}\text { protective } \\
\text { infrastructure }\end{array}$ & $\begin{array}{l}\text { - harden public facilities } \\
\text { and refuges } \\
\text { - locate power lines } \\
\text { underground } \\
\text { - augment water } \\
\text { requirements }\end{array}$ & $\begin{array}{l}\text { - } \text { subdivision layout } \\
\text { - subdivision layout } \\
\text { - subdivision layout }\end{array}$ & $\begin{array}{l}\text { - safeguard vulnerable } \\
\text { populations; provide } \\
\text { fallback for worst-case } \\
\text { conditions } \\
\text { - reduce ignition } \\
\text { potential } \\
\text { - ensure redundant } \\
\text { supplies; employ } \\
\text { exterior sprinklers }\end{array}$ \\
\hline
\end{tabular}




\section{Design Context: Landscape Setting}

\section{RRM: ENGAGE IN STRATEGIC PLANNING MUCH EARLIER}

California is fortunate that the state's Department of Forestry and Fire Protection (CAL FIRE) operates a Land Use Planning Program (LUPP) that provides input to counties preparing cyclical updates of their general plans. In this context, fire professionals affect the planning process - in an early and strategic way-but their involvement doesn't extend to day-to-day decisions about development at the local level. The LUPP assessment is primarily focused on the goals and policies in a general plan's safety element, and the criteria considered in the assessment are generally limited to issues covered in official state guidance on fire hazard. Nevertheless, this statewide land-use planning program plays an innovative and important role in determining where and how we build our communities in California.

Local fire professionals, in contrast, may become involved in the planning and permitting process relatively late and may therefore have little ability to argue for changes to a proposed development. By the time local fire professionals get involved, many decisions about siting and design on a landscape have already been finalized. Clearly, fire-related issues should be integrated into development planning decisions much earlier, especially when fire issues overlap with constraints on urban sprawl, concerns over natural hazards, or the desire for systematic multi-stakeholder community planning. The first RRM in the Landscape Setting context is, at an early stage in strategic planning processes that bear on local and regional development, to involve fire professionals and integrate fire-related concerns.

What mechanisms are available for allowing local fire-related professionals to get involved earlier? At the county level, Local Agency Formation Commissions (LAFCos) might be an appropriate mechanism. LAFCos, which guide growth and development and navigate interjurisdictional conflicts facing local agencies, are explicitly aimed at discouraging urban sprawl, in addition to enforcing "orderly development" in regions. (Note that more compact development, as we discuss later, is itself a community RRM for fire.) LAFCos also regulate the boundaries of cities and special districts, controlling a variety of changes (for example, annexations, disincorporations, mergers, establishments of subsidiary districts, and reorganizations). These functions include regulation of "growth-inducing" facilities and services such as fire protection. LAFCos can therefore indirectly guide land-use and development decisions in accordance with the RRMs identified here, if those agencies providing fire protection services in an annexed area or a new development district have endorsed such measures as their chosen standards. Making the case that development influences regional fire activity, well beyond a LAFCo's "sphere of influence" (as currently measured), is another possible way that fire-related concerns could enter into strategic planning decisions earlier.

Another avenue for earlier incorporation of fire-related concerns may be through local "economic development teams," which typically provide a seat at the table for public health and safety officials. In these settings, fire professionals can require that community-scale risk mitigation efforts, including measures identified here, be addressed (alongside other priorities) when an area is developed.

Less formal, ad hoc planning teams may be the easiest way to assemble individuals from relevant departments (for example, departments responsible for fire, planning and development, public works, transportation, and environmental protection) to review recently submitted development permits. Such an approach can build relationships between agencies, allow knowledge and information to be shared, and result in stronger requirements for buildings and developments. 


\section{Design Context: Landscape Setting}

\section{RRM: USE HAZARD MAPS}

If focusing development in the lowest-hazard portions of a landscape is a goal (see fig. 3, which highlights the Gaviota Coast as an example), how are such areas to be mapped and how is the goal to be accomplished? As with any natural hazard, some parts of a landscape will inherently be more prone to severe wildfire activity than others. At broad spatial scales, long-term fire frequencies are controlled by factors such as vegetation growth rates, the length and severity of the fire season, and ignition patterns. Exposure to extreme, local wind conditions-such as Santa Anas across Southern California, Sundowners in Santa Barbara, and Diablo winds in the Bay Area-is another major driver of fire activity and likely losses. At finer scales, dominant vegetation types in nearby areas, regardless of whether periodic fuel reduction is attempted, are one indicator of eventual fire behavior. Slope steepness and aspect will also drive eventual flame lengths and rates of spread.

All of the factors mentioned above vary spatially, often across relatively short distances. Therefore, when assessing a site for a subdivision, one of the first and most important considerations is how the location itself influences exposure to wildfire and potential for future losses of life and property. The second RRM in the Landscape Setting context is to avoid locating subdivisions in the highest-hazard portions of the landscape, thereby concentrating development in less dangerous areas. This is particularly true where hazard mitigation is not permanent (e.g., via short-lived fuel treatments) or hazard is driven largely by the physical environment (e.g., steep slopes, hot and dry winds).

At least four sources of mapped information can currently be used when evaluating options for locating a subdivision on a particular landscape. Each has its strengths and its most appropriate uses, but all reflect landscape fire hazard in some way. Often, CAL FIRE's Fire Hazard Severity Zone classifications dictate planning decisions about a given parcel, but decision makers should be aware that other mapped sources of fire hazard data are available. The data provided by these sources may be more specific, or presented at finer spatial scales, and therefore more appropriate for planning decisions at the level of individual parcels or of subdivisions. (Note: throughout this document we have used the term parcel instead of lot, though lot would sometimes also fit; see definitions in appendix A.)

- California Fire Hazard Severity Zones: This dataset ${ }^{1}$ was developed and is maintained by CAL FIRE. It reflects hazard rankings based largely on fire spread potential during standardized weather conditions (that is, the details of local fuel and topography are integrated, but wind, temperature, and humidity are applied uniformly statewide). Future versions will include local wind and weather extremes. The maps show fine-scale, parcel-level boundaries, but this level of detail is not necessarily available for differences in some environmental factors.

- Statewide Utility Fire Threat: This dataset ${ }^{2}$ was developed by the California Public Utilities Commission under the guidance of CAL FIRE. It integrates newly modeled wind and weather patterns (based on historical fire size distributions), updated fuels maps from the U.S. Forest Service, and sophisticated fire spread algorithms. This modeled dataset is an improvement over some other fire hazard maps-but due to the limitations of input data and the scale of intended use, the dataset's finest spatial resolution is 2-kilometer grid cells (fig. 4).

1. Fire Hazard Severity Zones Maps. CAL FIRE

2. CPUC Fire-Treat Maps and the High Fire-Threat District (HFTD) 
- U.S. Wildfire Hazard Potential: This U.S. Forest Service dataset ${ }^{3}$ integrates several fire modeling frameworks and statistically representative weather conditions (e.g., 80th, 90th, and 97th percentile worst) from distributed stations. The dataset's relatively fine spatial scale of 270 meters may be very appropriate for decisions about siting subdivisions, but the coarse-scale weather information used in generating the maps associated with the dataset will often miss important local characteristics.

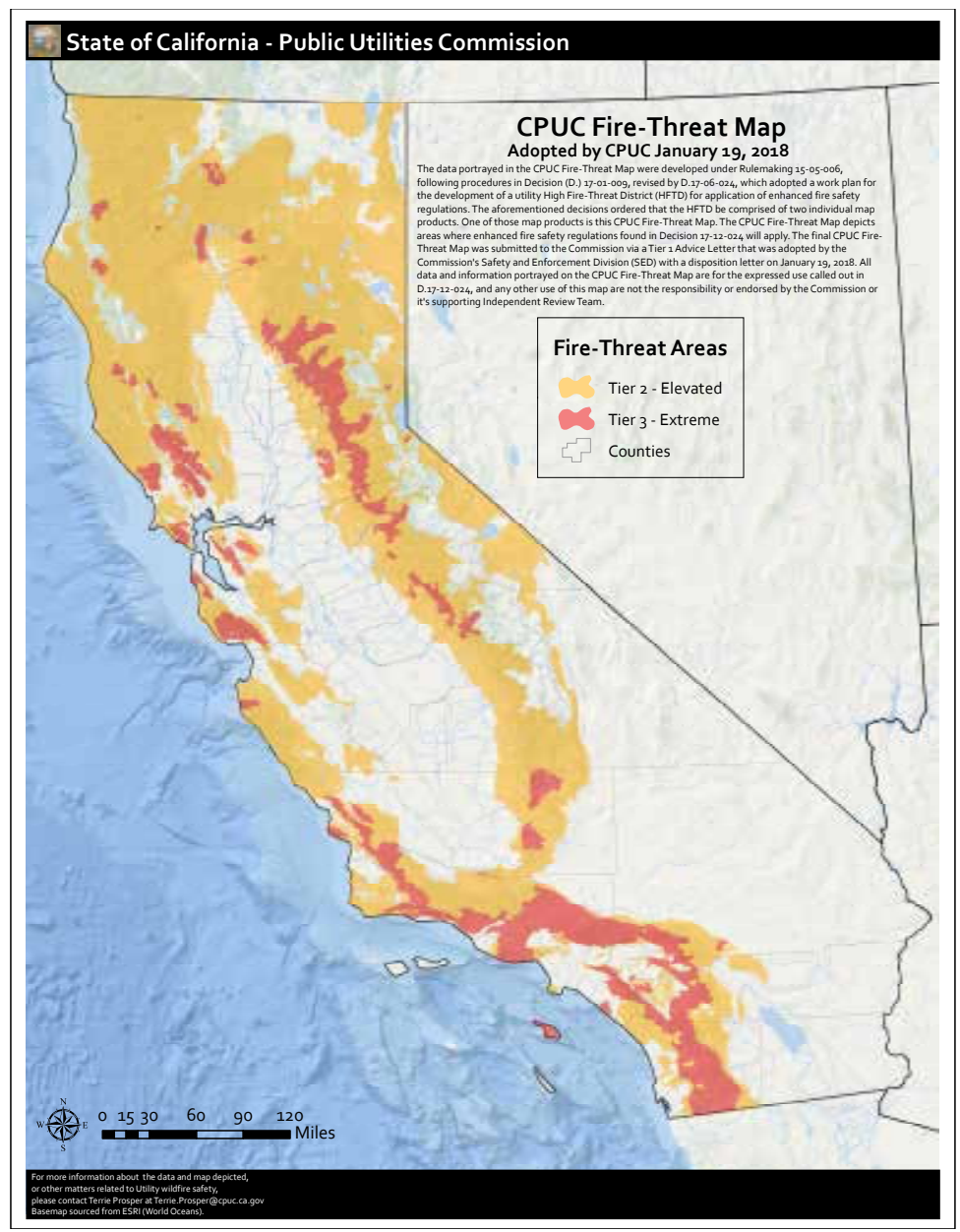

Figure 4. California State Public Utility Commission (CPUC) Fire Threat Map, adopted by CPUC on January 13, 2018.

Source: CPUC 2018.
- Fire Probability Models: These datasets ${ }^{4}$ were developed for projecting climate change effects on fire activity. They employ models based on environmental factors that control long-term fire frequencies (that is, biomass productivity, length and severity of the fire season, and ignition patterns). The datasets' historical "baseline" fire probability maps are thus useful for current siting decisions; however, because homes remain in place for decades once built, future scenarios may also be informative. The spatial resolution-1-kilometer grid cells-is relevant for fire frequencies, but not necessarily for fire behavior such as flame lengths. Recent versions include the influence of land development patterns on fire activity, which are as important as climate influences.

Using these relatively coarse-scale maps (e.g., fig. 4) to guide siting decisions on a fireprone landscape is directly analogous to the use of floodplain maps in land-use planning. As the methods and data underlying the maps are improved through time, decision-making based on these maps will likewise improve.

In addition to a given location's modeled wildfire hazard, nearby landscape-scale features can be obvious sources of danger. Topographic "chimneys" and large expanses of flammable vegetation (for example, unmaintained open space) are obvious examples of potentially dangerous landscape features to avoid, even if modeled fire hazard does not classify areas near them as hazardous. When possible, such features should be integrated with data products already available to improve local decision making. 


\section{Design Context: Landscape Setting}
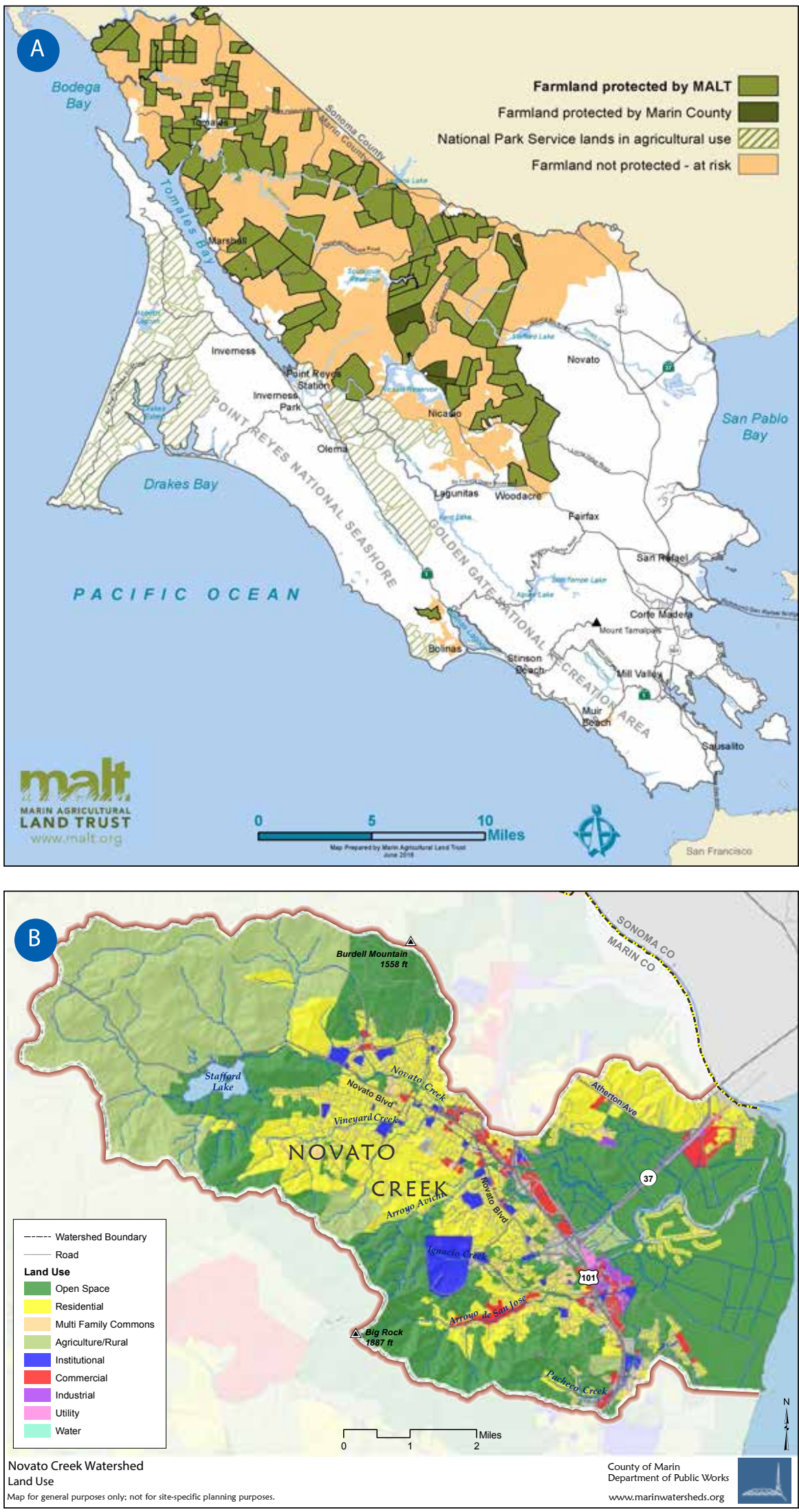

RRM: USE MAJOR

\section{LANDSCAPE FEATURES}

Though some landscape-scale features can be sources of wildfire hazard, others-such as water bodies, large irrigated parks, and swaths of agricultural land-can also provide protection against wildfire. It may be useful to evaluate such features when deciding where to allow subdivision development on an otherwise fire-prone landscape. The third RRM in the Landscape Setting context is to site subdivisions so they take advantage of major landscape features that can act as lasting buffers against oncoming wildfires.

It is very important to ensure that, when beneficial landscape features influence a siting decision, such features are preserved over the long term (for example, removing these features' protective designations when rezoning should be prohibited). In some regions, organizations dedicated to keeping agricultural lands in operation can assist in reducing wildfire vulnerabilities as an area is developed (fig. 5). Once a network of environmental buffers around

Figure 5. Agricultural lands in Marin County, California. County-wide agricultural land designations (A) and more localized zoning and potential development patterns that could take advantage of agricultural buffers (B).

Source A: MALT 2016. Source B: CMDPW 2017. 
the built environment is removed, reestablishing the network can be challenging because residential development exerts pressure against such land uses (fig. 6). Maintenance within these landscape features, to ensure that they do not fall into disuse and lose their buffering capacity, is also important.

Another way to use existing landscape characteristics to reduce overall exposure is to locate subdivisions adjacent to existing developments; this approach, however, requires that the density, layout, and building codes of the existing subdivisions decrease the risk of ignition and structure-to-structure propagation. In general, relatively contiguous development can decrease overall fire risk on the landscape. In contrast, a new subdivision could be at increased risk due to existing and less fire-resistant structures nearby. One might therefore aim to retain some major landscape feature (for example, an irrigated park) between a new subdivision and an older, more ignition-prone neighborhood.

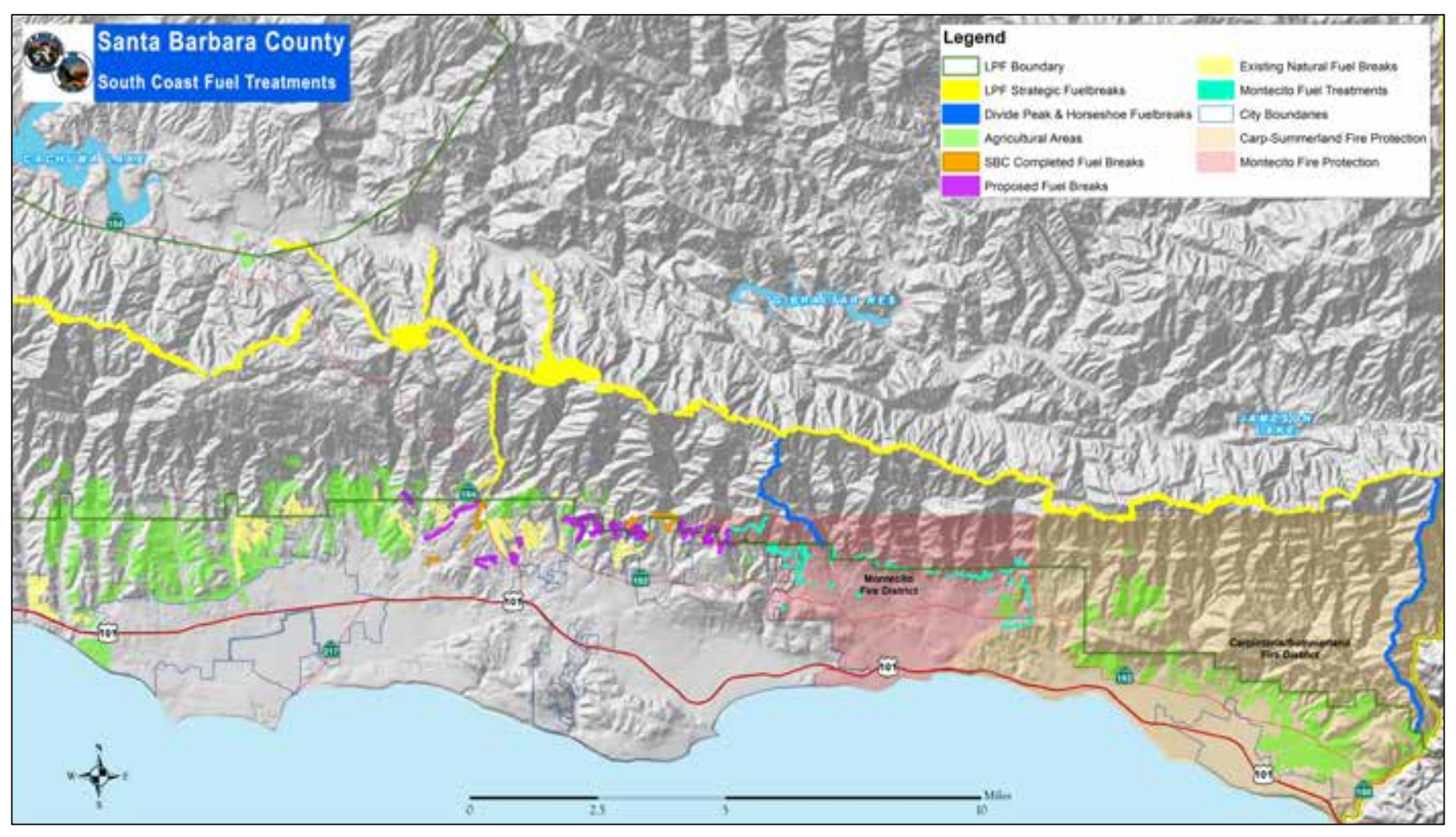

Figure 6. Fuel breaks and example land-use buffers along the Santa Barbara front range. Much of the Goleta area (toward the west) and the Carpinteria-Summerland area (toward the east) was historically protected by agricultural lands (shown in green) that buffered urbanized areas from the chaparral shrublands that dominate the region. Over time, orchards above Santa Barbara and Montecito were developed, largely as residential housing, exposing extensive portions of the built environment to much greater risk of wildfire.

Source: Santa Barbara County Fire Department. 


\section{Design Context: Separation from Wildfire Source}

\section{RRM: USE NON-FLAMMABLE AMENITIES}

At the finer spatial scale of subdivision layout, new fire-resistant neighborhood components can be arranged to increase the distance between structures and the source of wildfire hazard. In many cases, at least 100 feet of defensible space are required as a safe zone that allows firefighters to protect homes during a wildfire. This zone may also prevent burning vegetation next to the home from igniting the structure itself. Local jurisdictions or insurance companies may enforce stricter requirements for defensible space. While defensible space is crucial, new subdivisions can also employ neighborhood features-green infrastructure that is shared communally, or even parcel-level irrigated uses-to increase separation of homes
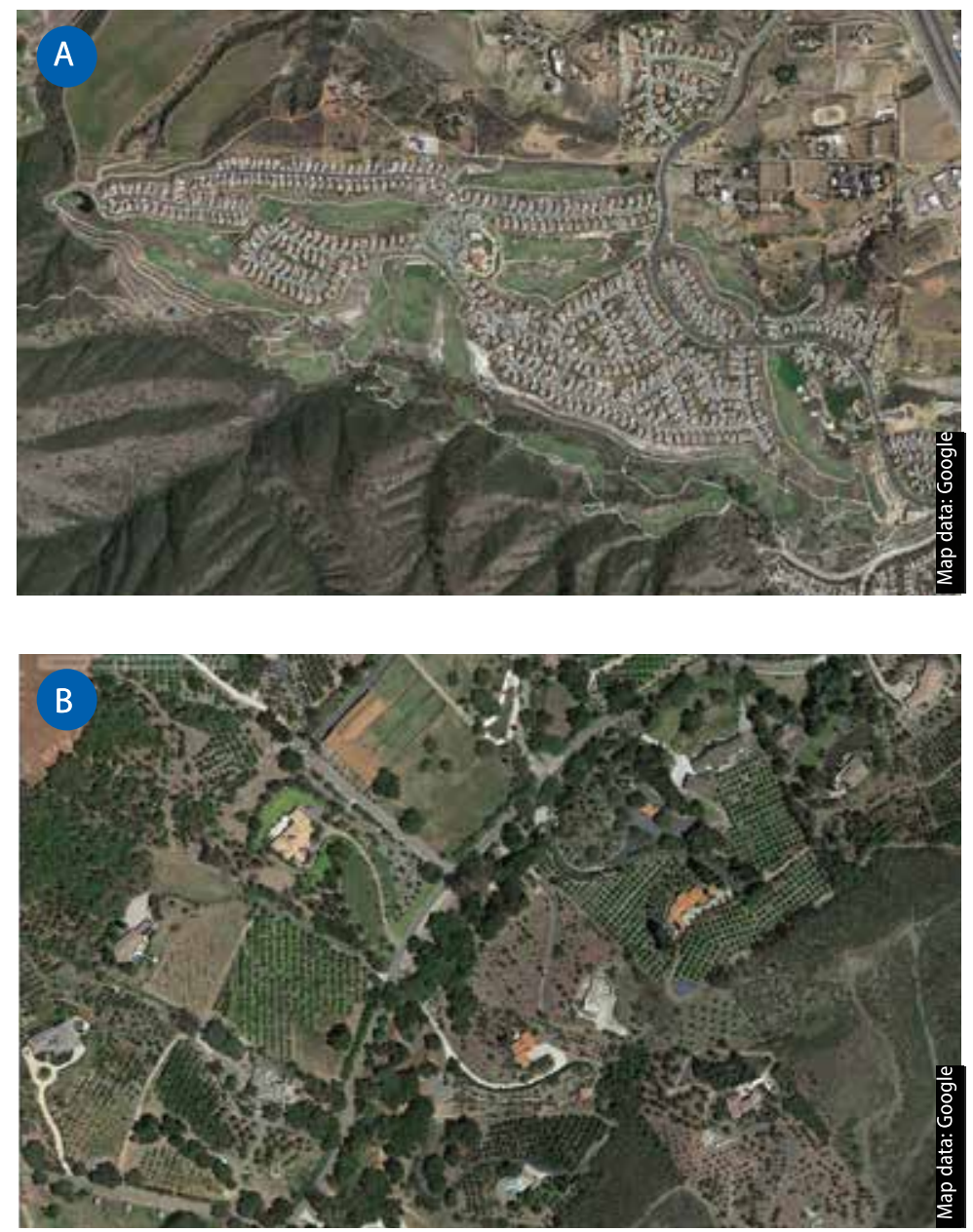

from flammable vegetation. The first RRM in the context of Separation from Wildfire Source is to use nonflammable amenities in the layout of a subdivision to maximize defensible space.

For example, the placement of shared amenities such as golf courses may lead to lower exposure for the full subdivision (fig. 7A). Likewise, for subdivisions that contain large areas of agriculturally productive land, designing some of those areas as "ranchette" units with backyard orchards or vineyards (fig. 7B) may also limit fire risk. It should be noted, however, that many components of a community can be flammable under the right conditions. Such amenities are therefore most effective as a buffer if the plants growing there are irrigated or naturally maintain relatively high water content in their leaves.

Ideally, nonflammable neighborhood components should be placed in such a way that they ring the subdivision and are part of a larger defensible-space strategy. Many of these same development concepts are incorporated into smart-growth guidance associated with creating greater compactness and livability for communities; an excellent fire-related example of this is shown in figure $8 \mathrm{~B}$, which depicts a development buffered by an "agricultural-urban interface." All protective neighborhood components must also be lasting-meaning that their ongoing maintenance and upkeep should be codified via the binding covenants, conditions, and restrictions that are common in homeowners' associations or other legal arrangements.

Figure 7. Golf course placement around a development near Arcilla, California, limits home exposure to wildfire (A). Small orchards near Escondido, Californiapossibly remnants from the past-provide a partial barrier for some homes (B). 

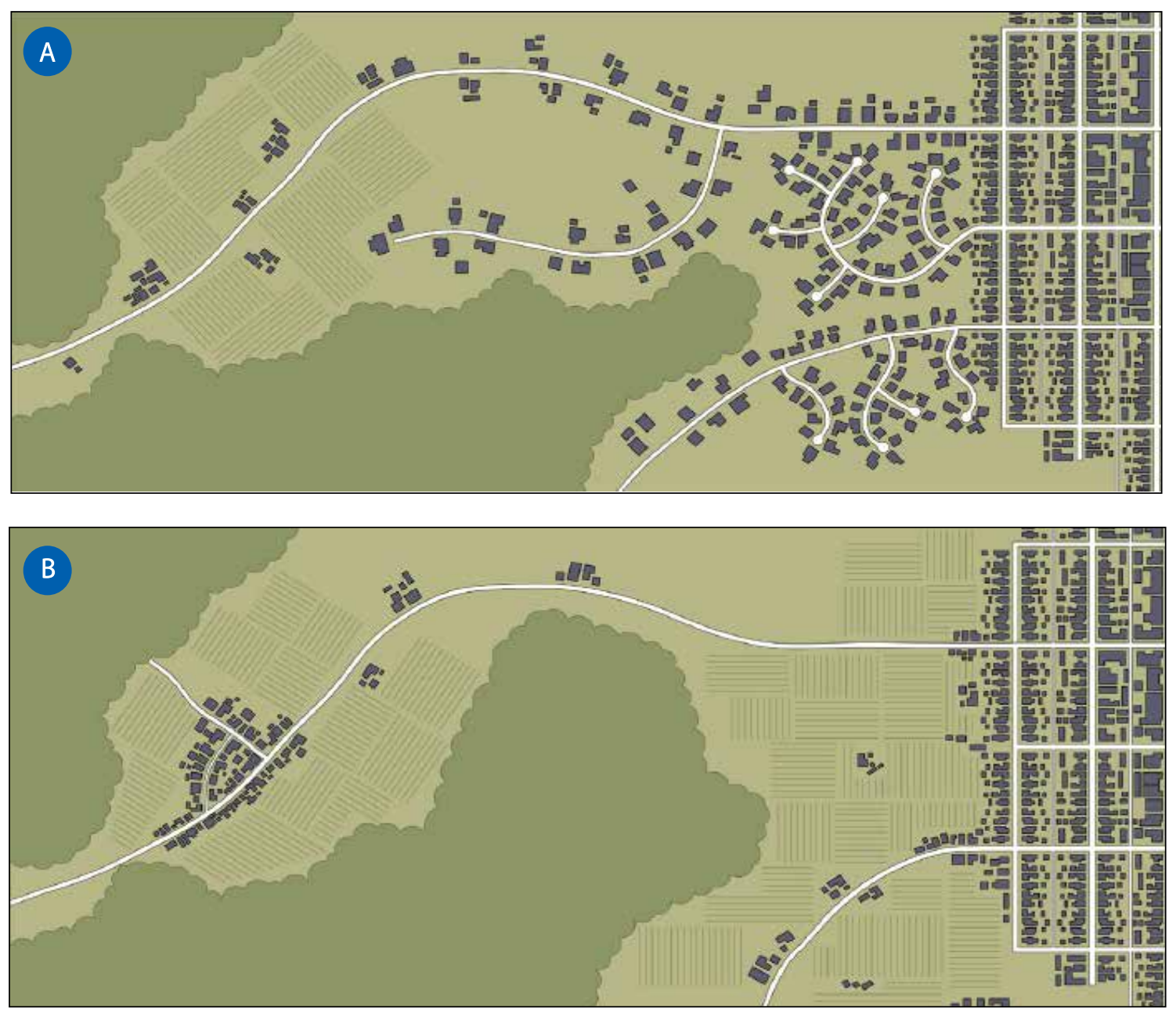

Figure 8. Comparison of conventional versus clustered development employing a protective agricultural buffer. A scattered pattern of conventional suburban sprawl (A) often transforms agricultural land (shown as striped rows) as development expands from a residential core (dense community on right). This development pattern requires greater area in "zones of defense" (light color) and thus more clearing of native vegetation (dark color); the more diffuse spacing of homes also requires more firefighting resources and makes fire suppression more complex.
An alternate development pattern (B) can provide the same total amount of housing as the scattered pattern, but is much safer and more effective because it retains (or creates) a protective "agricultural-urban interface" near the existing residential core, with clustered development and a protective agricultural-urban interface farther away. Homes built in this pattern will also be easier to defend from fire and require fewer fire suppression resources.

Source: Fire Mitigation in the Wildland Urban Interface: SmartCode Module. 


\section{Design Context: Separation from Wildfire Source}

\section{RRM: EMPLOY SAFE SETBACKS ON SLOPES}

Because homes with sweeping landscape views command higher prices, developers are often willing to build in the middle of slopes, or on top of them, to meet demand. However, developments on or near steep slopes can be at particular risk from wildfire because fire and heat generally flow faster uphill. This means that fire will naturally burn toward these homes, exhibiting long flame lengths that preheat the hillside, priming it for ignition and continually fueling its ascent toward hilltop homes. The danger increases with the angle of the slope, the extent of flammable downslope area, and the density of vegetation on the slope. If development must occur on slopes, an effective way to minimize exposure is to increase the distance between houses and the hillside flames. The second RRM in the context of Separation from Wildfire Source is to employ safe setbacks from the edge of a slope to maximize defensible space.
During fires, flames and heat will tend to bypass structures located farther from the edge of a slope (fig. 9). When development is located away from the edges of slopes, exposure is reduced because homes are not directly in the uphill flow of heat and flames. The risk to homes on the edges of slopes can be further reduced by clearing downslope vegetation or building a barrier, such as a wall or berm, in front of structures; however, these actions may also increase erosion and the potential for other natural hazards (for example, landslides).

In most cases, multiple factors argue for restricting development on or near steep slopes. These include the difficulty of safely evacuating on such steep terrain and the risks posed to firefighters as they defend the community.

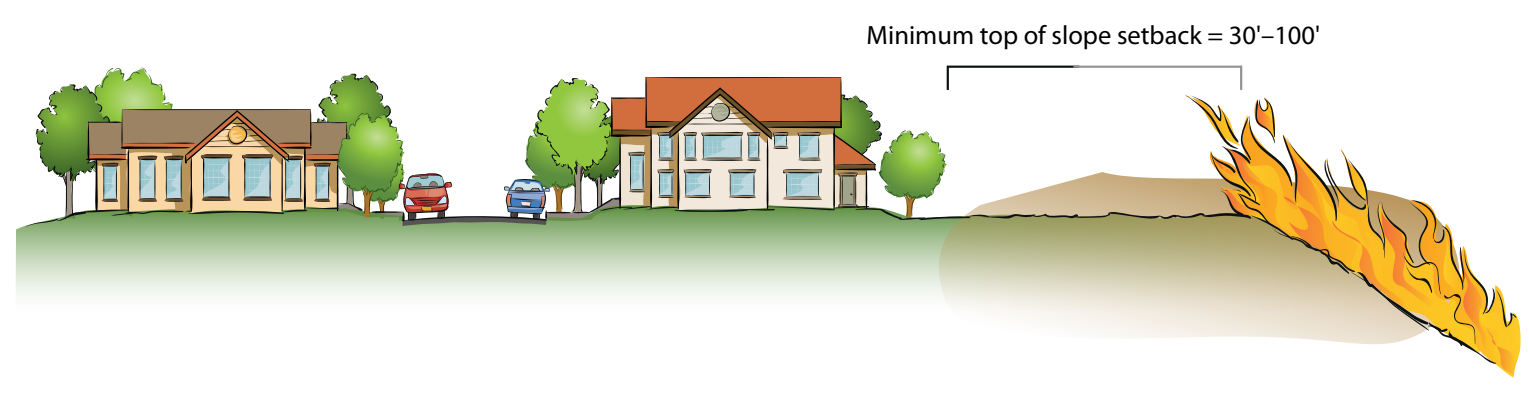

Figure 9. Development near slopes should be set back far enough from the slope's edge to provide safety from flames traveling upslope or lapping over the edge. Most guidance recommends a minimum safety area in the immediate "home ignition zone" of 30 feet; however, depending on the height of buildings and the potential flame lengths of burning vegetation on the slope, up to 100 feet may be needed. 


\section{Design Context: Separation from Wildfire Source}

\section{RRM: CONCENTRATE HOMES ALONG INNER SIDE OF ROADWAYS}

Neighborhood layout can help greatly in lowering the risk of home losses. A straightforward design principle that reduces risk is to restrict the placement of homes on perimeter roads around a given development, because homes abutting wildlands are more directly exposed to potential wildfire than homes in the interiors of developments. By locating structures on a road's less exposed side, designers allow the road itself to increase the distance to the hazard and act as added defensible space for structures. The third RRM in the context of Separation from Wildfire Source is to concentrate building of homes on the inner side of perimeter roads to maximize defensible space.

Some designs, unlike typical neighborhood layouts, limit the number of homes placed on perimeter roads (fig. 10). Depending on the location and the development, concentrating homes on the inner side of a perimeter road may not mean building fewer homes overall (for example, parcel sizes can be smaller).

Although this design strategy lowers risk, other considerations must be addressed. For example, a development's road network is a crucial component of evacuation planning and implementation. It may therefore be important for evacuation purposes to provide alternatives to perimeter roads, as firefighters might be actively working there during a wildfire. (Another design approach might be to reduce the neighborhood's perimeter-to-area ratio, further separating homes from flammable hazards.)

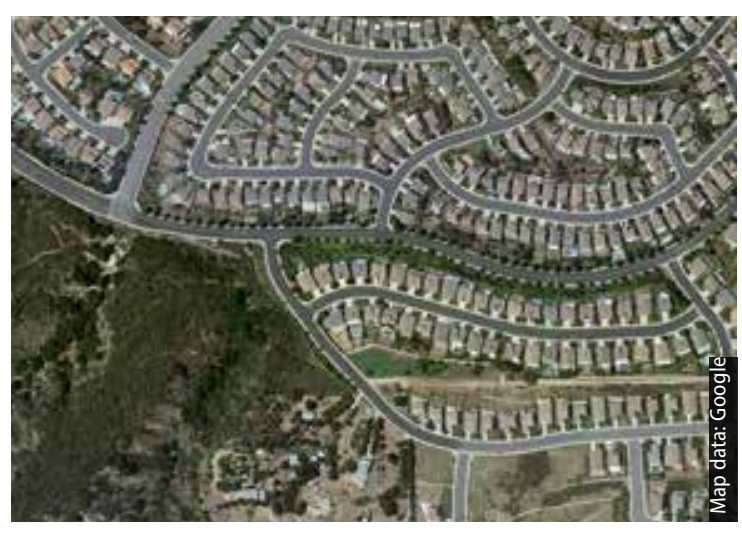

Figure 10. Localized concentration of homes on the inner side of a perimeter road near Alberhill, California. Roads, sidewalks, and yards all become defensible space between the wildlands and structures when homes are sited in this fashion. 


\section{Design Context: Density Management}

\section{RRM: CLUSTER WITH OTHER HOMES}

Historically, wildfires have destroyed more homes built at low and medium densities than at high densities. During recent, severe fires in the WUI (for example, the 2018 Camp Fire in Paradise, California) and amid "urban conflagrations" (for example, the 2017 Tubbs Fire in Santa Rosa, California), it appears that homes themselves were often the fuel that carried fire to other homes, regardless of the distance between the homes. Nonetheless, the design, maintenance, and use of defensible space for fire protection is easier when neighborhoods are developed more densely and are built to stringent fire-resistant building codes. Such neighborhoods are more compact and easier to defend with a smaller firefighting force, and also help achieve goals for climate resiliency and other aspects of livability. The RRM in the Density Management context is to cluster structures to reduce collective exposure.

In addition, denser neighborhoods often have lower amounts of flammable vegetation and more pavement, making them generally less flammable in the first place (fig. 11). Combining clustered and more compact development with buffering patches of less-flammable land uses (for example, commercial or smallscale agriculture) can lead to several synergistic benefits (for example, safe pedestrian and biking infrastructure); figure 8 provides a good example of how this can be achieved.

While densely developed homes are generally less likely to burn than dispersed homes, it is crucial that dense developments be built with the best fire-resistant construction methods and most stringent defensible-space requirements. Otherwise, the closer spacing can lead to structure-to-structure ignition and potential urban conflagrations. Effective evacuation plans should be created for such developments because higher local concentrations of people also imply a need for greater ingress and egress capacity in the road network. The need for local refuges, if evacuation efforts fail, should also be accommodated.

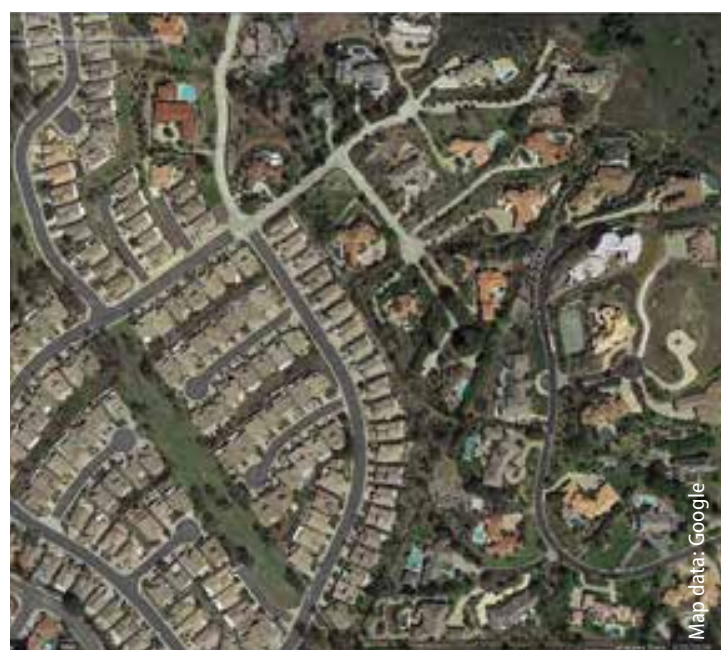

Figure 11. High- versus low-density development north of Poway, California. Tighter clustering of housing decreases amounts of flammable vegetation, which makes defensible space easier to maintain. During a wildfire, high-density development can also be defended more easily and with fewer resources. 


\section{Design Context: Protective Infrastructure}

\section{RRM: HARDEN PUBLIC FACILITIES AND CREATE REFUGES}

During a typical fire, vulnerable populations such as senior citizens and young children may not be evacuated quickly or easily. Therefore, it is important that facilities housing these populations be made as fire-safe as possible. Schools, nursing homes, and hospitals should be located in the less exposed interior areas of communities, and structures should be built to resist ignition. Furthermore, under extreme circumstances-when fire is spreading rapidly or evacuation information is lacking-late evacuation can be deadly for anyone. In critical situations, these structures may act as shelter-in-place refuges of last resort for multiple populations; the alternative might be mass fatalities amid stalled traffic during a widespread evacuation. The first RRM in the Protective Infrastructure context is to construct fire-resistant public facilities and create community refuges to provide safety for vulnerable populations and last-resort options for worst-case conditions.

Relatively few local refuges of last resort have been established, largely because fire agencies tend to emphasize full evacuation of entire communities. However, recent fires in California-especially the 2017 Tubbs Fire and the 2018 Camp Fire-have demonstrated that some fraction of the population will inevitably not evacuate in time and may be killed as a result. In Australia, the 2009 Black Saturday fires resulted in many fatalities, which led to a variety of planning and policy changes. These included the establishment of a small number of local refuges.

Constructing or retrofitting key structures to provide temporary refuge during a wildfire is different from maintaining preidentified "safety zones." Safety zones can save lives, but they tend to be open areas with little flammable vegetation (for example, golf courses or large parking lots); such areas may need to be several hundred feet in diameter, depending on vegetation height and environmental conditions (that is, surrounding slope steepness and winds) $)^{5}$. Refuges, in contrast, can be buildings with a much smaller footprint, designed to provide reliable protection from radiant heat and embers long enough for the intense flaming front of a fire to pass through an area (for example, a minimum of 30 to 60 minutes), and also to provide enough space and air for the people who may occupy the refuge. Recognized requirements for such structures have been developed in Australia (fig. 12), and may provide a model until U.S. standards are developed. Such buildings will likely need to exceed the strongest codes available from CAL FIRE and the Office of the State Fire Marshal for the WUI.

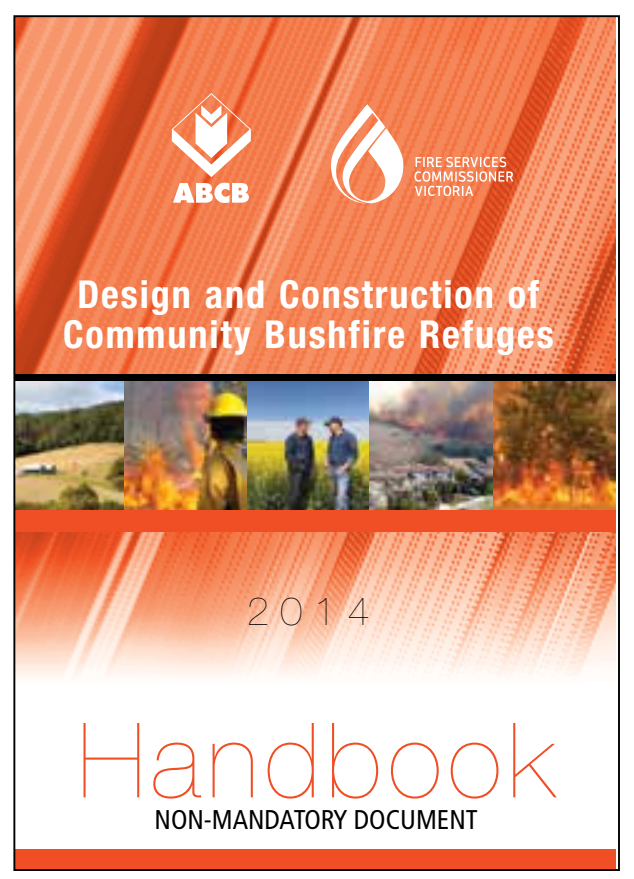

Figure 12. Few last-resort refuges have been established in the United States, but recent fires in the WUI have demonstrated that refuges should be considered in some developments.

5. For example, see: Creating a "Safety Zone" for Wildfire Emergency. Mendocino County FireSafe Council and 6 Minutes for Safety. National Wildlife Coordinating Group 


\section{Design Context: Protective Infrastructure}

\section{RRM: LOCATE POWER LINES UNDERGROUND}

In recent years, utility power lines-and their potential to cause large, damaging fires-have become an issue of great concern. As more of California's fire-prone landscapes are developed, and climate change threatens to make many environments even more flammable in the future, utility-caused fires may become an even more critical problem. One proposed solution is to locate power lines underground so they are less prone to causing ignitions during extreme wind conditions (for example, due to infrastructure failure or to trees or limbs falling on power lines). A side benefit to locating power lines underground is aesthetic: namely, one's view is not affected when power lines are underground. This benefit is especially appealing for new subdivisions because installing underground power lines on undeveloped lands is relatively easy. The argument for underground power lines is even stronger in recognized areas of high wildfire risk. The second RRM in the Protective Infrastructure context is to require new developments to place power lines underground to eliminate them as ignition sources during extreme wind conditions.

It should be noted that statewide regulations ${ }^{6}$ require that funds be set aside for removing overhead lines and replacing them with underground service in existing communities. Regulations also require new subdivisions to provide underground access for all new distribution and service connections. ${ }^{7}$
However, these requirements do not apply if parcels were legally described before 1970 and significant overhead lines already exist within the development; thus, new construction may be exempt from this safeguard. Additional exceptions are possible based on minimum parcel sizes (for example, 3 acres). Also noteworthy is that regulations do not require undergrounding in developments that are rebuilt following wildfires. Local jurisdictions can impose ordinances that include more stringent requirements, but it is not clear how often they do so.

Burying power lines can be expensive, especially where lines are already installed aboveground. This is an argument against mandating that power lines be placed underground. Underground power lines can also be more difficult to repair and may be more susceptible to other problems than traditional aboveground lines (for example, seismic or flood damage).

Despite these challenges, the benefits of undergrounding may sometimes outweigh the costs, especially in certain high-risk areas. ${ }^{8}$ In addition, when the costs of losing many homes in wildfires and subsequently rebuilding are included-costs that now routinely enter into the billions of dollars-investments in underground power lines, along with their long-term maintenance, may not appear as daunting.

6. Undergrounding. CPU

7. Rule15, Distribution Line Extensions.pdf. Southern California Edison and Rule16, Service Extensions.pdf. Southern California Edison

8. In fire protection test, PGE installing underground lines along rural Sonoma county road. The Press Democrat 


\section{Design Context: Protective Infrastructure}

\section{RRM: AUGMENT WATER REQUIREMENTS}

Many articles in professional journals discuss the challenges of delivering water for fire suppression purposes when centralized supplies or hydrants are lacking. ${ }^{9}$ During a fire event, it is also possible for water pressure to drop drastically, even when supplies would otherwise be available and sufficient. ${ }^{10}$ Therefore, despite requirements for adequate public water supplies in new developments, private local water supplies can become a critical resource for firefighting in extreme situations. New residential developments often must comply with requirements concerning interior sprinkler systems; exterior sprinkler systems are also used in some environments, even where not required. For the safety of both homeowners and firefighters, augmenting water-related requirements is a positive step. The third RRM in the Protective Infrastructure context is to require exterior sprinklers and additional on-site water storage to increase fire suppression capacity.

The use and maintenance of private water supplies can present several challenges, including the compatibility of hose and valve fittings. Serious issues can also arise when water storage systems are not filled, maintained, and periodically tested, rendering them useless. As an RRM, these details need to be standardized and documented, as with municipal water supply systems and the accepted guidelines for their operation. ${ }^{11}$ One of the more progressive approaches to local private water supplies has been developed by the Fire Safe Council of Mendocino, California, which provides homeowners guidance for such systems. San Diego County has also created standards for private water supplies. Both of these examples are included in appendix B.

Exterior sprinklers have proponents but some groups are less supportive ${ }^{12}$; a fact sheet that covers some of these issues is provided in appendix C. Open questions surround sprinklers' effectiveness, especially in extreme conditions, as well as their effect on water pressure over a larger area. Local on-site water supplies may thus be essential when exterior sprinklers are employed. Even with local water supplies, it may be difficult to time exterior sprinkler use to coincide with the greatest wildfire exposure-that is, when embers are present or the flaming front approaches-so that supplies are not depleted early. FEMA provides guidelines for both interior and exterior sprinklers in residential construction ${ }^{13}$, and use of such systems will likely increase in the future.

9. For example, see: FDIC 2018: Rethinking Rural Water Supplies. Training video

10. For example, see: Some fire hydrants didn't work because of power outages, firefighters say. LA TImes

11. Regarding tanks, connections, and testing, see: List of NFPA Codes \& Standards. nfpa.org

13. Fire Sprinklers, Home Builders Guide to Construction in Wildfire Zones.pdf. FEMA 


\section{RISK REDUCTION MEASURES AND ENVIRONMENTAL CONCERNS}

Land-use planning and urban design can create both synergies and trade-offs where protection of biological resources and environmental values are concerned.

\section{Pockets of Native Vegetation}

Many of the RRMs presented here focus on increasing development density; greater density ameliorates environmental concerns because it requires less land use and road construction and prevents sprawl. In some cases, local topography tends to push development into certain areas, leaving other portions of a landscape-such as embedded canyons or creeksundeveloped and open. In addition, pockets of open space within neighborhood developments are often appreciated by community residents, and these open spaces can provide useful habitat for native plants and animals. Some vegetation types, however, are inherently more flammable than other types, and fire is required in the life cycle of certain native plants, so the design of open space in subdivisions must be carefully planned.

Smaller interior pockets of vegetated open space should be designed so that they maintain relatively high water content in their leaves, reducing the chances that fire will spread if burning embers land there.

If this approach is followed, integrating these smaller open or green spaces into evacuation plans (for example, as local temporary safety zones) also becomes a possibility.

Larger interior pockets of open space, because they are likely to contain native and possibly more flammable vegetation, should be surrounded by defensible space, with homes placed along the interior side (that is, as if positioned along a perimeter road).
The planning and design of subdivisions should account for the fact that these larger interior pockets of vegetation may burn periodically.

\section{Prioritization of Biological Resources}

When fire professionals weigh in on planned developments, key decisions about protecting biological resources may have already been made. If so, options for implementing the RRMs presented here are clearly limited; their effectiveness may be limited as well. On the other hand, fire professionals may invoke public safety concerns that can override environmental protection measures. The result can be legal confrontations in which all sides lose.

To the degree possible, when planners address the protection of biological resources, they should work in tandem, throughout the design and approval process, with fire professionals who assess concerns over fire hazard and vulnerability.

Ideally, this process would include input from local conservation organizations. Such an approach would facilitate regional planning efforts-concerning, for example, protection of important habitat corridors-and avoid both incremental degradation of biological resources and the potential for legal conflicts. Early involvement by varied stakeholders in the land-use planning and urban design process could sometimes complicate decision-making but, over the long term, a "landscape approach" should allow for a more holistic process and lower risk levels for both people and the biological resources that we value. This recommendation overlaps to a considerable extent with the need to engage in strategic planning much earlier (i.e., the first RRM highlighted in this document). Involvement of both fire and biological resource professionals before various siting and design options have been eliminated can help lead to planning decisions that better integrate these issues. 


\section{REFERENCES}

Alex, K., S. Morgan, B. Rubin, C. Calfee, and N. Glover. 2014. Fire hazard planning: general plan technical advice series. Sacramento, California: Governor's Office of Planning and Research.

Alexandre, P. M., S. I. Stewart, M. H. Mockrin, N. S. Keuler, A. D. Syphard, A. Bar-Massada, M. K. Clayton, and V. C. Radeloff. 2016. The relative impacts of vegetation, topography, and spatial arrangement on building loss to wildfires in case studies of California and Colorado. Landscape Ecology 31(2):415-430. https://doi.org/10.1007/s10980-015-0257-6

Alexandre, P. M., S. I. Stewart, N. S. Keuler, M. K. Clayton, M. H. Mockrin, A. Bar-Massada, A. D. Syphard, and V. C. Radeloff. 2016. Factors related to building loss due to wildfires in the conterminous United States. Ecological Applications 26(7):2323-2338. https://doi. org/10.1002/eap.1376

Bihari, M., E. M. Hamin, and R. L. Ryan. 2012. Understanding the role of planners in wildfire preparedness and mitigation. ISRN Forestry 2012:253028. https://doi. org/10.5402/2012/253028

Blonski, K. S., C. Miller, and C. L. Rice. 2010. Managing fire in the urban wildland interface. Point Arena, California: Solano Press Books.

Brzuszek, R., J. Walker, T. Schauwecker, C. Campany, M. Foster, and S. Grado. 2010. Planning strategies for community wildfire defense design in Florida. Journal of Forestry 108(5):250-257.

Butsic, V., M. Kelly, and M. Moritz. 2015. Land use and wildfire: a review of local interactions and teleconnections. Land 4(1):140-156. https://doi.org/10.3390/land4010140

Buxton, M., R. Haynes, D. Mercer, and A. Butt. 2011. Vulnerability to bushfire risk at Melbourne's urban fringe: the failure of regulatory land use planning. Geographical Research 49(1):1-12. https://doi.org/10.1111/ j.1745-5871.2010.00670.x

(CMDPW) County of Marin Department of Public Works. 2017. Novato Creek watershed land use. https://www.marinwatersheds. org/sites/default/files/2017-05/W_Novato_ LandUse.pdf
(CPUC) California Public Utilities Commission. 2018. CPUC fire-threat map. ftp://ftp. cpuc.ca.gov/safety/fire-threat_map/2018/ PrintablePDFs/8.5X11inch_PDF/CPUC_FireThreat_Map_final.pdf

Duany, A., J. Speck, M. Lydon, and E. Goffman. 2010. The smart growth manual. New York: McGraw-Hill.

Duerksen, C., D. Elliott, and P. Anthony. 2011. Addressing community wildfire risk: a review and assessment of regulatory and planning tools. Final report for the Fire Protection Research Foundation by Clarion Associates. http://www.fstaresearch.org/ resource/?FstarId=11309.

(FEMA) Federal Emergency Management Agency and California Office of Emergency Services. 2008. Southern California best practices: Southern California wildfires of 2007. Report 1731-DR-CA.

(FEMA) Federal Emergency Management Agency Region X. 2013. Integrating the local natural hazard mitigation plan into a community's comprehensive plan: a guidebook for local governments. Report 07053-13.

Gonzalez-Mathiesen, C., and A. March. 2014. Nine design features for bushfire risk reduction via urban planning. Australian Journal of Emergency Management 29(3):2936.

Gross, P. 2009. Golf courses on the fire line. Green Section Record, NovDec edition:13-16. http://gsr.lib.msu. edu/2000s/2009/091113.pdf.

Hakes, R. S., S. E. Caton, D. J. Gorham, and M. J. Gollner. 2017. A review of pathways for building fire spread in the wildland urban interface part ii: response of components and systems and mitigation strategies in the United States. Fire Technology 53:475. https:// doi.org/10.1007/s10694-016-0601-7

Headwaters Economics. 2016. Land use planning to reduce wildfire risk: lessons from five Western cities. https://headwaterseconomics. org/wildfire/solutions/lessons-five-cities/

(MALT) Marin Agricultural Land Trust. 2016. Marin Agricultural Land Trust: 10 things you should know. http://www.farmtoforksf.org/ blog/2016/9/30/marin-agricultural-land-trust10-things-you-should-know 
Mann, M. L., E. Batllori, M. A. Moritz, E. K. Waller, P. Berck, A. L. Flint, L. E. Flint, and E. Dolfi. 2016. Incorporating anthropogenic influences into fire probability models: effects of human activity and climate change on fire activity in California. PLoS One 11(4):e0153589. https://doi.org/10.1371/ journal.pone.0153589

March, A., and Y. Rijal. 2015. Reducing bushfire risk by planning and design: a professional focus. Planning Practice and Research 30(1):33-53. https://doi.org/10.1080/02697459 .2014 .937138

Moritz, M. A., E. Batllori, R. A. Bradstock, A. M. Gill, J. Handmer, P. F. Hessburg, J. Leonard, S. McCaffrey, D. C. Odion, T. Schoennagel, and A. D. Syphard. 2014. Learning to coexist with wildfire. Nature 515(7525):58-66. https://doi. org/10.1038/nature13946

Mowery, M., A. Read, K. Johnston, and T. Wafaie. 2019. Planning the Wildland-Urban Interface. American Planning Association, PAS Report 594.

(NACo) National Association of Counties, International Fire Chiefs Association, and National Association of County Planners. 2010. Planning fire-resilient counties in the wildland-urban interface.

(NFPA) National Fire Protection Association. 2013. Community wildfire safety through regulation: a best practices guide for planners and regulators. http://catalog.nfpa.org/ Community-Wildfire-Safety-ThroughRegulation-A-Best-Practices-Guide-forPlanners-and-Regulators-P552.aspx.

Opie, K., A. March, J. Leonard, and G. Newnham. 2014. Indicators of fire vulnerability: risk factors in Victorian settlements. CSIRO and Melbourne University report to the Natural Disaster Resilience Grants Scheme. https://msd.unimelb.edu.au/climate-changeadaptation-suitability-indices-humansettlement-fire-vulnerability.
(SBCPDD) County of Santa Barbara Planning and Development Department. 2016. Gaviota Coast Plan. http://longrange. sbcountyplanning.org/planareas/gaviota/ documents/Final\%20Documents\%201-182017/Plan\%20by\%20Chapter/5.0\%20Land $\% 20$ Use.pdf.

Stein, S. M., J. Menakis, M. A. Carr, S. J. Comas, S. I. Stewart, H. Cleveland, L. Bramwell, and V. C. Radeloff. 2013. Wildfire, wildlands, and people: understanding and preparing for wildfire in the wildland-urban interface - a Forests on the Edge report. Gen. Tech. Rep. RMRS-GTR-299. Fort Collins, Colorado: U.S. Department of Agriculture, Forest Service, Rocky Mountain Research Station.

Syphard, A.D., T. J. Brennan, and J. E. Keeley. 2017. The importance of building construction materials relative to other factors affecting structure survival during wildfire. International Journal of Disaster Risk Reduction 21:140-147. https://doi. org/10.1016/j.ijdrr.2016.11.011

Syphard, A. D., V. C. Radeloff, J. E. Keeley, T. J. Hawbaker, M.K. Clayton, S. I. Stewart, and R. B. Hammer. 2007. Human influence on California fire regimes. Ecological Applications 17(5):1388-1402. https://doi. org/10.1890/06-1128.1

Syphard, A.D., H. Rustigian-Romsos, M. Mann, E. Conlisk, M. A. Moritz, and D. Ackerly. 2019. The relative influence of climate and housing development on current and projected future fire patterns and structure loss across three California landscapes. Global Environmental Change 56:41-55. https://doi. org/10.1016/j.gloenvcha.2019.03.007

Tachieva, G. 2010. Sprawl Repair Manual. Island Press.

\section{APPENDIX A: GLOSSARY OF TERMS}

Agricultural-urban interface: The line, area, or zone where structures and other human development meet or intermingle with neighboring agricultural lands, which can buffer the built environment from oncoming wildfire.
Amenities: Landscape features such as parks, golf courses, or natural areas that may contribute to human welfare. Strategic siting of developments in tandem with amenities can reduce fire risk. 
Defensible space: Area of relatively sparse vegetation near structures. In California, the minimum defensible space is 100 feet. Defensible space 1) provides firefighters an area in which to defend a home against wildfire and 2) creates an area with low fuel loads, to limit the spread of fire from vegetation to a structure.

Exposure: The presence of assets or values. In the context of fire, exposure often refers to the spatial distribution of people or homes that might be harmed by fire or its effects.

Federal Responsibility Area: Area of a state in which federal firefighting agencies are responsible for fire protection. Generally, this is land owned by the federal government.

Hazard: A real or potential threat. In the context of fire, hazard often refers to characteristics of fire behavior, such as flame length, rate of spread, heat release, and fire frequency.

In-fill development: A type of development that occurs when new structures are built within the perimeter established by existing structures. In-fill can occur when vacant lots within already established communities are developed. Such development helps limit new exposure to wildfire.

Local Responsibility Area: Area of a state, typically inside municipal boundaries, in which local firefighting agencies are responsible for fire protection.

Lot: Generally, a building site with fixed boundaries on a map, typically with some form of street access. In reference to land, lot is sometimes used interchangeably with parcel.

Parcel: Generally, a unit of ownership or development, which may contain one or more lots.

Risk: Potential for adverse consequences whose occurrence and degree are uncertain. In the context of fire, risk is a function of the patterns and frequencies of fire (hazard), the locations of assets or values (exposure), and the susceptibilities of those assets or values to harm (vulnerabilities).
Shelter in place: To stay in or near a structure during a wildfire as opposed to evacuating the area. Sheltering in place may be planned for, as is the case when specific structures are designated as areas where people can take refuge during wildfire, or may be an act of last resort when evacuation is no longer possible.

State Responsibility Area: Portion of California where CAL FIRE is responsible for fire protection. Typically, State Responsibility Areas are privately owned lands in nonagricultural rural areas, but they also include much of the WUI adjacent to more densely populated areas.

Subdivide: To divide land into smaller units, typically to make the land easier to sell or develop. The area encompassed by the former larger parcel is typically referred to as a subdivision.

Vulnerability: Susceptibility or sensitivity to harm. In the context of fire, vulnerability often refers to people's ability to cope or respond (for example, their preparation for evacuation or their mobility) or the ignition potential of the built environment (for example, flammable wood roofs and vents-in sidings, attics, and crawl spaces-that allow ember penetration).

Water content of leaves: The amount of water relative to the amount of leaf tissue, also known as "live fuel moisture" (that is, the ratio of wet weight to dry weight). Higher water content slows ignition because, for combustion of leaves and associated twigs to occur, water must first be driven off via heating (from, for example, nearby burning material).

Wildland-urban interface (WUI): The line, area, or zone where structures and other human development meet or intermingle with undeveloped wildland or vegetative fuels. Lands in the WUI are particularly susceptible to fire because they include populations that cause ignitions, vegetation or other materials that can burn (including homes), and challenges to fire suppression due to the spatial arrangement of houses. 


\section{APPENDIX B:}

\section{Local water supply guidance examples from San Diego County ${ }^{14}$ and Mendocino Fire Safe Council'15; also see City of Morgan Hill' ${ }^{16}$.}

\section{San Diego County Fire Authority \\ WATER TANK STANDARDS FOR FIRE PROTECTION}

\section{MINIMUM WATER STORAGE TO PROVIDE PROTECTION FOR DWELLINGS AND OTHER STRUCTURES, WHERE ADEQUATE PUBLIC/PRIVATE WATER SUPPLY IS NOT AVAILABLE}

NOTE: In areas where water can be supplied by pumps from a domestic source, such systems must be reviewed by the Fire Authority Having Jurisdiction (FAHJ).

\begin{tabular}{|c|c|c|c|}
\hline \multicolumn{4}{|c|}{ TABLE NO. 903.3.2 } \\
\hline Building Square Feet & Gallons Per Minute Water Flow & Capacity Gallons & Duration Minutes \\
\hline $\begin{array}{l}\text { Up to } 1,500 \\
\text { Over } 1,500\end{array}$ & $\begin{array}{l}250 \\
250\end{array}$ & $\begin{array}{l}5,000 \\
10,000\end{array}$ & $\begin{array}{l}20 \\
40\end{array}$ \\
\hline \multicolumn{4}{|c|}{$\begin{array}{l}\text { When exposure distance is one hundred feet }\left(100^{\prime}\right) \text { or less from adjacent property, the following } \\
\text { minimum fire flow shall be adhered to. Increases in water storage may be required by the Chief, } \\
\text { depending on the square footage of the exposed structure. When protecting exposures within } 100 \text { feet } \\
\text { or less, the minimum flow duration shall not be less than two (2) hours unless otherwise approved by } \\
\text { the Chief. }\end{array}$} \\
\hline \multicolumn{2}{|c|}{\begin{tabular}{|l|l} 
EXPOSURE DISTANCE & \\
\end{tabular}} & \multicolumn{2}{|c|}{ MINIMUM FIRE FLOW } \\
\hline \multicolumn{2}{|c|}{$\begin{array}{l}\text { Over } 100 \mathrm{Ft} . \\
31 \mathrm{Ft} .-100 \mathrm{Ft} . \\
11 \mathrm{Ft} .30 \mathrm{Ft} . \\
10 \mathrm{Ft} . \text { or less }\end{array}$} & \multicolumn{2}{|c|}{$\begin{array}{l}250 \text { Gallons Per Minute } \\
500 \text { - } 750 \text { Gallons Per Minute } \\
750 \text { - } 1000 \text { Gallons Per Minute } \\
1000-1500 \text { Gallons Per Minute }\end{array}$} \\
\hline
\end{tabular}

If buildings are contiguous, a minimum of 2,500 gallons per minute shall be required.

Water Tank Location:

1. Tank elevation shall be equal to or higher than the fire department connection on the premises. Regardless of domestic use, all tanks shall be equipped with a device that will ensure that the tank contains the designated amount of water for fire flow duration as determination by the fire department. Tank size may be increased to serve multiple structures on a single parcel.

2. Supply outlet shall be at east 4 inches in diameter from the base of the tank to the point of outlet at the fire department connection. The fire department connection shall be at least one 4-inch National Standard Thread (male), reduce to one $2 \frac{1}{2}$ inch National Standard Thread (male). Additional outlets may be required.

3. Location of the fire department outlet to be determined on the plot plan when submitted to the fire department. Consideration will be given to topography, elevations, and distance from structures, driveway access, prevailing winds, etc.

4. The outlet shall be located along an access roadway and shall not be closer than 50 feet nor further than 150 feet from the structure.

5. All exposed tank supply pipes shall be of an alloy or other material listed for above ground use. Adequate support shall be provided.

6. Water storage tanks shall be constructed from materials approved by the Fire Marshal and installed per manufacturer recommendations.

7. The Chief may require any necessary information to be submitted on a plot plan for approval.

8. Vessels previously used for products other than water shall not be permitted. 


\section{Fire Protection Water Tank Installation Standards}

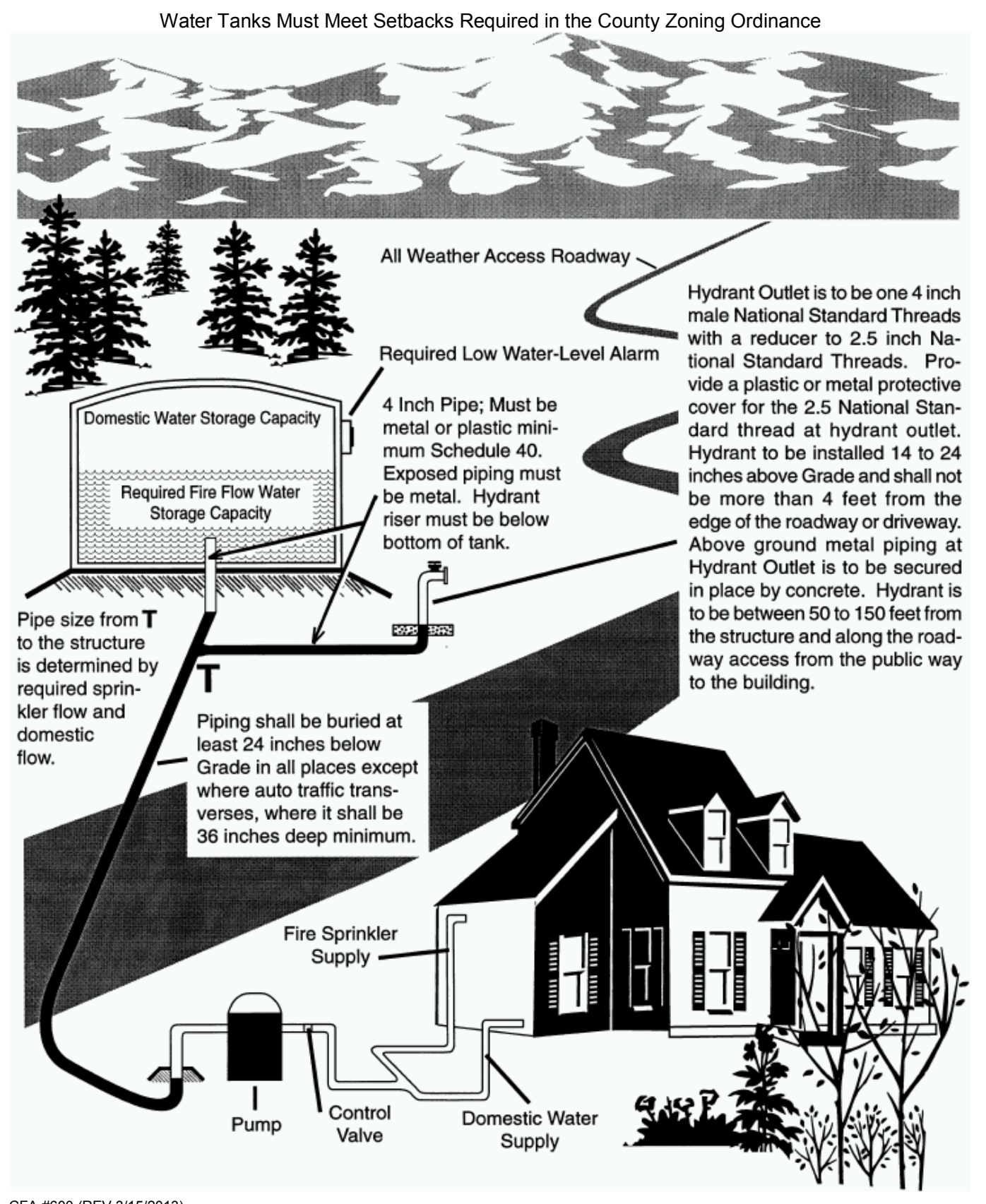

CFA \#600 (REV 3/15/2013)

5510 OVERLAND AVENUE, SUITE 250, SAN DIEGO, CA 92123 • (858) 974-5999 http://www.sdcounty.ca.gov/sdcfal 


\section{DEVELOPING WATER SUPPLIES FOR FIRE PROTECTION}

In rural areas, water for firefighting is often hard to find. Every year, many homes are lost because water was not available to fire personnel. The homes may have had thousands of gallons of water but it was in tanks firefighters could not access, because the tanks lacked the correct fittings.

This pamphlet describes how to make your rural water supply accessible for fire protection. It gives general information only. Any persons developing water supplies for fire protection should consult with their local fire department to ensure they are complying with local standards.

\section{Mendocino County Fire Safe Council}

\section{CAUTION}

Fighting wildfires can be very dangerous. Persons planning to defend their own homes must take this fact seriously. They must be in good physical condition, and they must have a place to take shelter if the situation gets beyond their control. The decision to stay and fight a wildfire or to evacuate must be made based on conditions at the time of the fire. If evacuation is required, allow plenty of time to reach safety. Most people who die in wildfires are trying to evacuate, too late.

\section{DRAFT AND PRESSURIZED SYSTEMS}

Water systems designed for fire protection come in two basic types: (1) draft only systems, which provide water without pressure, and (2) pressurized systems, with the pressure provided either by a pump or by gravity.

\section{Draft Systems}

The simplest type of fire protection water system consists of a tank fitted with a standard 21/2" male National Hose pipe thread fitting (sometimes called a "fire thread" fitting) controlled by a valve. This system requires the responding fire engine to attach a suction hose to the fitting and to draft, or suck, the water into the engine's pump, where it is pressurized. Because fire engines carry only a short suction hose, the fitting must be located so the engine can park very close to it. CAL FIRE (CDF) requires this to be a maximum of 7 feet. The parking location and the approach to it should be a hard surface capable of supporting a fire engine in any weather.

If it is impossible to park an engine this close, the resident must install some form of hydrant at an accessible, suitable location. We'll discuss this later.

Although a draft system usually meets minimum requirements and is the cheapest, it limits firefighters' options and takes more time to utilize. A draft system must provide unimpeded access between the fire fitting and the water supply. No pumps can be installed on the line, and the line cannot be connected to the domestic (home) water supply. Drafting creates a great deal of suction that could damage a domestic pump. A fire engine might

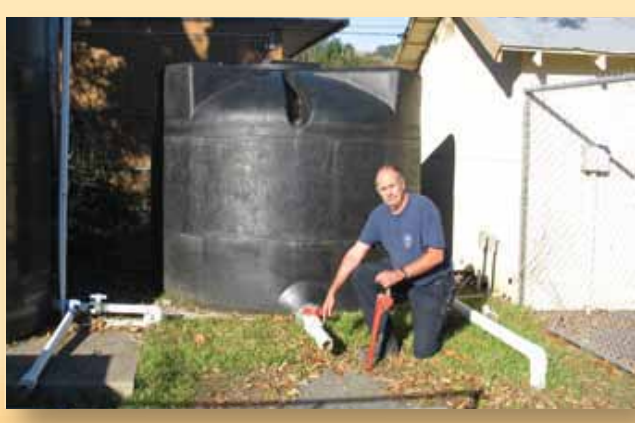

be unable to establish a draft because of drawing air through the pump or domestic supply.

Draft systems sometimes use a "dry" hydrant. A dry hydrant is a pipe connecting a water supply below ground level (such as a tank or pond) to an above-ground hydrant. When opened, the hydrant produces no water - the responding fire engine must lift the water by creating suction. Dry hydrants can be extremely problematic and should be avoided if possible.

Much more dependable is a "flooded" or "wet" hydrant. Such a hydrant already contains water because the water source is located higher than the hydrant. Even though a flooded hydrant may provide no pressure, it is far easier for a fire engine to establish the draft and get water flowing when the water line and hydrant are full or "primed." A tank slightly lower than is needed can be placed on platform that raises it to the necessary height. Water weighs about eight pounds per gallon so any such platform must be strongly constructed.

2. Pressurized Systems

There are two ways to provide pressure to a water system: using gravity, or using a pump. 


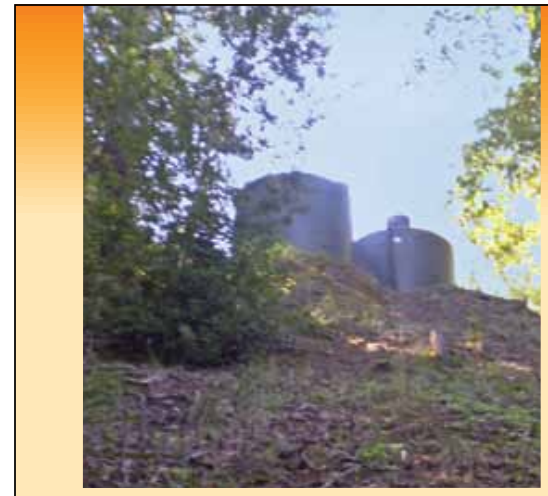

\section{a) Gravity Systems}

Gravity systems are generally the most dependable and desirable for fire protection. The typical domestic system - which pumps water directly from a well to a pressure tank to the home - utilizes small diameter water lines and low volume pumps which are insufficient for fire protection. Further, during fires, electrical service is frequently lost, and pumps fail, just when water is needed the most. Gravity systems may cost more because they require larger pipes and more tanks. But they will not fail when the power goes out!

In a gravity system, water is collected in or pumped to an elevated tank before it is needed. This tank is kept full and water is brought down to the home through a large diameter pipe. We'll show later that gravity systems can combine both domestic and fire protection water.

Elevating a tank above the point where the water is used provides one pound of pressure for every 2.3 feet in elevation gain. A tank placed 230 feet above the house will provide 100 pounds of static pressure. $\boldsymbol{A}$ tank $\mathbf{8 0}$ feet above the house will provide 35 pounds of pressure - the approximate minimum needed to protect a home.

A gravity system intended only for supplying a fire engine could have much less pressure and still be very effective, but only if (1) the water line is at least $21 / 2$ " in diameter (preferably 3 " or more) and (2) the line is short with no humps or rises that can trap air, making drafting difficult or impossible.

\section{b) Portable Pumps}

Small, portable water pumps are another option for providing pressure. They can be used with tanks, in-ground or above-ground pools, ponds, streams, or any available water source. Numerous styles and sizes meet virtually any need. We strongly recommend that water pumps be pre-fitted with fittings with male National Hose thread on the discharge side of the pump. A $11 / 2$ "fitting is adequate for systems for home fire defense only.
Persons planning to defend their homes themselves should use a $11 / 2^{\prime \prime}$ fitting and $11 / 2^{\prime \prime}$ hose, as a $21 / 2^{\prime \prime}$ hose filled with pressurized water is extremely awkward and too heavy for most persons to pull. Check with your local fire department for their preference.

Portable pumps require a suction hose with compatible fittings and enough length to access the available water source: for example, a 10 -foot hose for a swimming pool 8 feet deep.

If water is being drawn from a source where dirt, gravel, or other materials might be sucked in, the pickup/intake end of the suction hose should be equipped with a strainer. Small particles may pass through a pump without a problem, but they will almost certainly clog your fire nozzle at an inopportune time! The pickup must be protected by suspending it above the bottom of the water source or placing a shovel or similar object under it.

Some strainers come with a built-in "foot valve" that prevents water from flowing

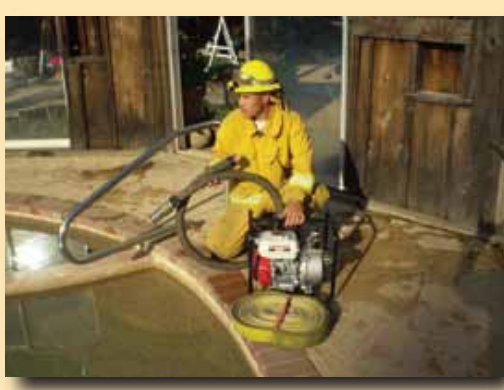

backwards out of the hose. This is very helpful in initially establishing flow through the pump and maintaining flow if you need to stop and re-start the pump. The discharge should be compatible with your fire department's fittings.

\section{WATER TANK SELECTION, INSTALLATION, AND PLUMBING}

\section{Tank Selection}

Water tanks come in a wide variety of sizes, shapes, and materials. The tank you select will depend on your intended use, your budget, and where it will be installed. The green plastic free-standing tanks seen in rural areas are the most common for both domestic and fire protection purposes. The cheapest storage per gallon we found was a 3,000-gallon plastic tank about eight feet wide and eight feet tall. Most of these come with a standard (non-fire) 2" discharge fitting. Larger discharge fittings can be installed, and two or more tanks can be plumbed together and merged into a larger diameter pipe if needed.

The size and number of tanks needed depends on a few factors. When building a new home, you may be required by CAL FIRE or your local fire department to provide water for fire protection, generally 2,500 gallons. You may be allowed to use the same tank for both domestic and firefighting purposes IF you place the domestic discharge high enough on the tank that the water below it meets the fire requirement. For example, a 5,000-gallon tank could have the domestic water discharge/outlet halfway up the tank. The fire discharge comes off the bottom of the tank so it can utilize all water in the tank at any time. For most rural residential properties, 2,500 gallons is plenty for fire protection - IF you have done adequate clearing of vegetation around your buildings. Contact CAL FIRE, your local fire department, or the Mendocino County Fire Safe Council for information about this aspect of wildfire safety.

\section{Tank Installation}

Where and how to install tank(s) depends on the system's use. A single tank from which a fire engine can draft water must be located as

described on page 1. Tanks for a gravity system,

the better choice, should be located between 80 and 230 feet above the home. Typical desired home water pressure is 40 to 60 pounds, which a 90 to 140 feet elevation will provide. The 100 pounds of pressure provided by a 230 rise is too much for most home systems, but is excellent for fire protection.

If more than one tank is used, the tops of all tanks must be at the same elevation. If one tank is higher than another, the high tank will overfill the low one, causing it to discharge water from the overflow. When tanks are plumbed or manifolded together, each should have its own shutoff valve so if one tank develops a leak it can be isolated. A single $2 \frac{1}{2} 2^{\prime \prime}$ draft fitting can utilize all the tanks; and if installed at the same elevation, all tanks will draw down equally as water is used.

Plastic tanks should be protected from fire by clearing around them just as you clear around your buildings. Any adjacent burnable material must be reduced so the tank can survive when that material burns. Even full plastic tanks will melt when exposed to enough heat.

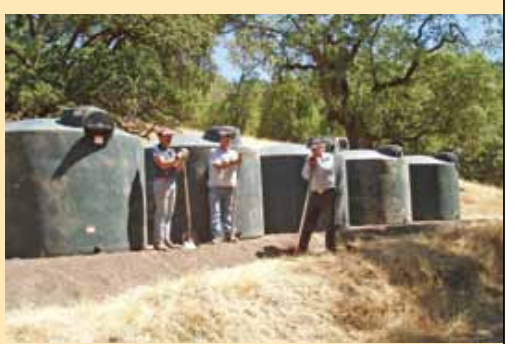

Tank Plumbing

The most common problem with adapting existing systems for fire protection is the size of the water pipe. Most domestic systems use either $3 / 4^{\prime \prime}$ or 1 " pipe. This is enough to supply a garden 
hose - but not a fire hose. We recommend a minimum of 2" pipe for systems supplying $11 / 2$ " fire discharges and 3" pipe for 21/2" discharges. Systems with multiple fire discharges may require larger pipes if more than one discharge might be used at the same time.

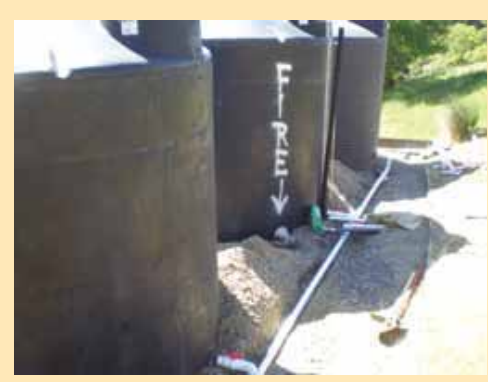

\section{HYDRANTS}

PVC pipe is normally used to bring water to the hydrant; and PVC or galvanized iron pipe is often used for the riser/hydrant.

Various fittings can be used for the valve and discharge of your Fire Department Connection (FDC). We recommend using a "Wharf Valve," also called a "Fire Valve," which comes in $1 \frac{1}{2}$ " and $21 / 2$ " sizes. The inlet fitting on the valve's bottom is standard pipe thread, either male or female. The discharge/outlet is $11 / 2$ " or $21 / 2$ " male National Hose thread. A round wheel on the top controls the valve. These valves are somewhat expensive but are quality products and relatively trouble free. Standard PVC ball valves also work well, but they are more easily damaged and have a shorter working life, particularly when exposed to sunlight. All valves and FDCs should be painted red.

Hydrants should be set in a bed of concrete, especially draft hydrants. The suction hose required to use draft hydrants is very heavy and awkward, making it easy to damage or break a

PVC pipe even if the riser is galvanized. Another problem is "water hammer," which occurs when a large volume of moving water is suddenly stopped when the valve is closed. Setting the hydrant in a substantial concrete base provides stabilization to protect against both these situations.

If a PVC riser is used, a strong support must be provided, because a firefighter pulling on a hose can easily snap PVC. Support can be provided as follows. Put a sleeve of 6" PVC over the riser and set it into the concrete base as an outer shell. Then fill the space between the riser and the shell with concrete. When the concrete sets, a solid, durable 6 " barrel of concrete is set into the base or thrust block as one unit. Be sure to check thoroughly for leaks before you pour the concrete! Mark the riser with blue reflectors. Consult your local fire department for their specific requirements. Hydrants should be located a short distance away from the house. CAL FIRE requires 50 feet. At this distance, if the house is on fire you can likely still access the hydrant. The ideal location will allow firefighters to park near the hydrant and reach a fire anywhere inside the home with their pre-connected, 150-foot-long hose. Some homes may require more than one hydrant.

Outbuildings may require their own. One option is multiple $11 / 2$ " hydrants with a 100 -foot-long single $1 \frac{1}{2}{ }^{\prime \prime}$ fire hose and nozzle available to each hydrant. Inexpensive plastic fire nozzles will flow about 60 gallons per minute.

We strongly recommend storing fire hose in an elevated cabinet next to the hydrant, to protect it from sunshine and the elements. We also recommend using synthetic hose, as cotton hose

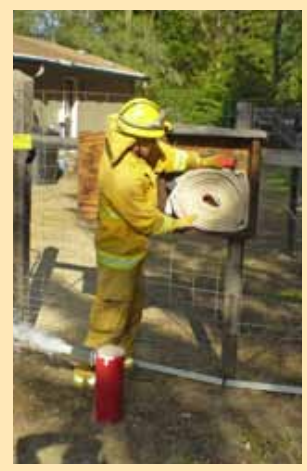
can rot quickly. Nozzles should be pre-connected to the hoses, and fire hose cabinets should be clearly marked and easy to access Hydrants should be 18 to 24 inches high. State law requires that they be placed 4 to 12 feet from any road. Be sure to keep grass and brush at least 8 feet away, so hydrants can be found and accessed during a fire. If hydrants could be hit by vehicles, protect them with barriers such as large rounds of firewood or concrete filled tubes. Hydrant discharges should be covered with screwed-on metal caps that prevent objects or creatures from getting into the pipes and being drawn into a fire engine or hose when the water is pumped.

\section{MODIFYING EXISTING WATER \\ SYSTEMS}

In summary, if your current system can deliver at least 40 gallons per minute, it can be easily adapted for firefighting by simply providing a $1 \frac{1}{2}$ " or $2 \frac{1}{2} 2^{\prime \prime}$ male National Hose pipe thread fitting where $a$ fire engine can access it.

- If a fire engine can park within 7 feet of the tank, put the fitting and valve at the base of the tank.

- If an engine cannot get that close, install a pipe from the tank to a location the engine can reach, generally next to the driveway or parking area, and build your hydrant there.

\section{Building a Siphon}

If your tank doesn't have a large enough discharge port and it isn't practical to install one, consider building a siphon using $21 / 2$ " or 3 " PVC pipe and elbows, as shown in the diagram on the back of this pamphlet.

1) Cut a length of PVC pipe that is 6 inches shorter than the height of your tank.

2) Cut a length of pipe 12 inches shorter than the height of your tank.

3) Cut a 6 "-12" length of pipe and connect it to the first long pipe with a $90^{\circ}$ elbow.

4) Put this section through the top of the tank, so the long pipe's bottom is 6 inches above the tank's bottom and the short pipe rests on the top edge of the tank

5) Connect the second long pipe (\#2) to the short piece, outside the tank, with another elbow. The bottom of this pipe should be about 12 " above ground level.

6) Install either a "wharf valve" or PVC ball valve on the bottom of the pipe.

7) Cut and install another short length of pipe straight below the valve.

8) Cut and install another short length of pipe and connect it with a $90^{\circ}$ elbow. This short pipe should be angled slightly away from the tank.

9) Finish the fitting with a $21 / 2^{\prime \prime}$ male National Hose thread adaptor.

These instructions may not precisely match your circumstances. See the diagram for details.

The outside siphon pipe should be secured to the tank if possible. If not, set a 4 " $\times 4$ " or larger post next to the tank and secure the pipe to it, being careful not to obstruct the valve or discharge fitting.

The siphon is established by pumping water into the tank through the fire fitting, then closing the valve. Once established, the siphon should take care of itself; it can be easily re-established if necessary.

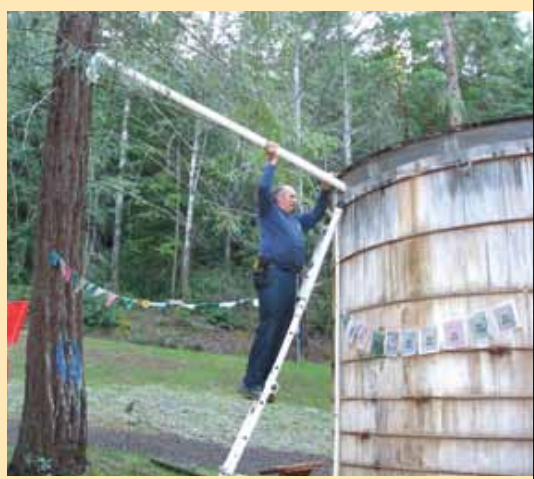

If your existing system is not sufficient or adaptable, consider purchasing a tank solely for fire protection. Place the tank at least 80 feet above the house, or as high as is practically possible. Use at least a 2" water line, and up to a 3 " line if affordable and the size of the water supply justifies the expense. 


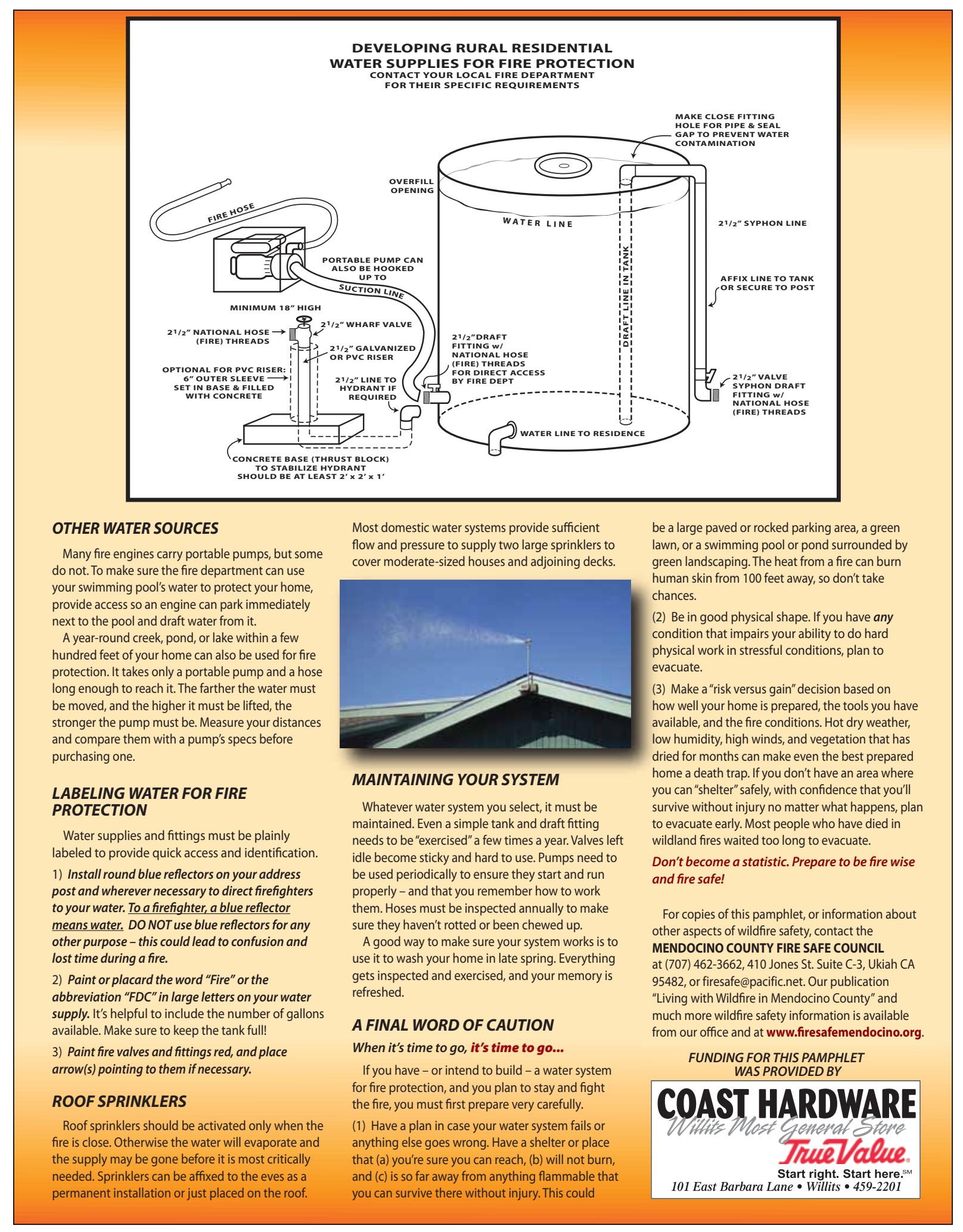




\section{APPENDIX C:}

\section{Exterior sprinkler fact sheet ${ }^{17}$.}

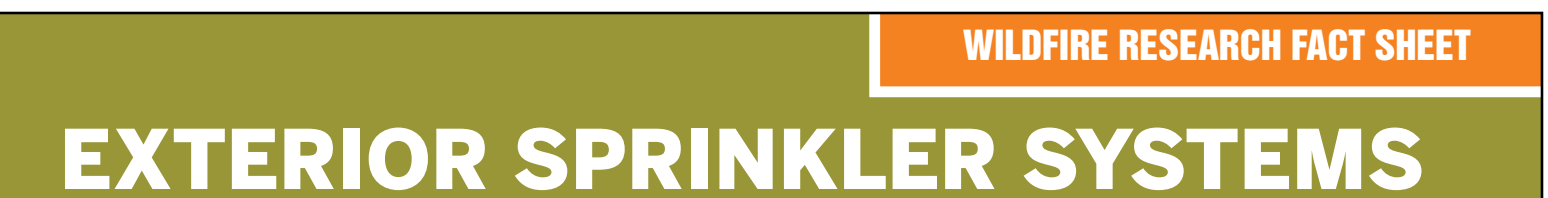

Are exterior sprinkler systems an option for protecting a home during a wildfire, after residents have evacuated the property?

\section{Functionality and Installation}

The function of an exterior sprinkler system is to minimize the opportunity for ignition by wetting the home and surrounding property. Sprinkler systems should be able to protect a home against the three basic wildfire exposures: wind-blown embers, radiant heat and direct flame contact.

Sprinklers systems can be mounted in one or more locations, including:

- The roof (Photo 1)

- Under the eave at the edge of the roof.

- On the property, in which case the sprinklers are directed at the home from multiple locations surrounding it.

Ember ignition of combustibles located on or near the home can result in a radiant and/or flame contact exposure (Photo 2). Water should reach all vulnerable areas for the system to have maximum effect both on and near the home (Photo 3).

\section{Potential Issues}

Post-fire assessments have shown exterior sprinkler systems can be effective in helping a home survive a wildfire, but potential issues exist with their use. These issues include:

- The water supply should be adequate to deliver water, when needed, for the time embers could threaten a home. This period could be up to 8 hours.

- Check with your local fire department if your sprinkler system uses water from a municipal supply; they may have suggestions to help minimize water consumption.

- The effectiveness of a sprinkler system is questionable when a neighboring home is burning, since this would result in an extended radiant heat and/or contact exposure to the home.

- These systems can be activated manually or by an automated device, such as a sensor that detects heat or flame, or by an SMS-enabled cell phone. The ability of these systems to activate based strictly on an ember exposure has not been determined. Since wind-blown embers can be transported for up to a mile from the flame front of a wildfire, this may be a limitation.

- The most threatening wildfires occur during high-wind events and the homeowner should consider how the distribution/transport of water droplets may be influenced by elevated wind speeds.

\section{Recommendations}

Given the potential issues regarding performance, it's recommended that use be a supplement to, and not a replacement for, already proven mitigation strategies, such as the reduction of potential fuels throughout the home ignition zones, along with removal of roof and gutter debris, and use of noncombustible and fire/emberignition resistant building materials and installation design details.
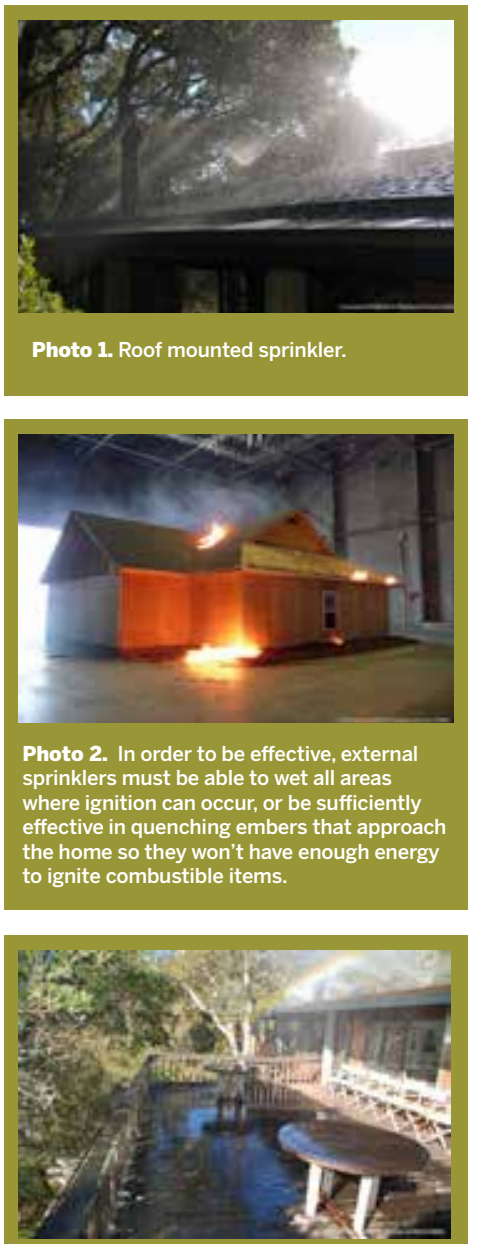

Photo 3. Roof-edge mounted sprinkler. Photo 3. Roof edge mounted sprinkler. in the near- sprinklers did not deliver water in the near-home area. With this scenario, a sufficient number of wind-blown embers would have to be quenched in order to avoid ignition of the siding and decking in this zone, particularly at the deck-to-wall intersection.

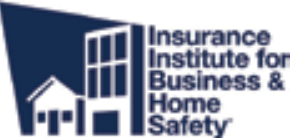

\section{WFP WIREWISE USA}

This publication was produced in cooperation with the USDA Forest Service, US Department of the Interior and the National Association of State Foresters. NFPA is an equal opportunity provider Firewise and Firewise USA ${ }^{\oplus}$ are registered trademarks of the National Fire Protection Association, Quincy. MA. Firewise USA is a program of the National Fire Protection Association.

17. For examples of sprinkler systems, with no endorsement implied, see: Wildland firefighter invents exterior sprinkler system. firerescue1.com and Report examines effectiveness of outdoor sprinkler systems during wildfires. wildfiretoday.com 
To order or obtain UC ANR publications and other products, visit the UC ANR online catalog at https://anrcatalog.ucanr.edu/ or phone 1-800-994-8849. Direct inquiries to UC Agriculture and Natural Resources

Publishing

2801 Second Street

Davis, CA 95618

Telephone 1-800-994-8849

E-mail: anrcatalog@ucanr.edu

(C)2020 The Regents of the University of California. This work is licensed under the Creative Commons AttributionNonCommercial-NoDerivatives 4.0 International License. To view a copy of this license, visit https://creativecommons.org/ licenses/by-nc-nd/4.0/ or send a letter to Creative Commons, PO Box 1866, Mountain View, CA 94042, USA.

Publication 8680

\section{ISBN-13: 978-1-62711-133-1}

The University of California, Division of Agriculture and Natural Resources (UC ANR) prohibits discrimination against or harassment of any person in any of its programs or activities on the basis of race, color, national origin, religion, sex, gender, gender expression, gender identity, pregnancy (which includes pregnancy, childbirth, and medical conditions related to pregnancy or childbirth), physical or mental disability, medical condition (cancer-related or genetic characteristics), genetic information (including family medical history), ancestry, marital status, age, sexual orientation, citizenship, status as a protected veteran or service in the uniformed services (as defined by the Uniformed Services Employment and Reemployment Rights Act of 1994 [USERRA]), as well as state military and naval service.
UC ANR policy prohibits retaliation against any employee or person in any of its programs or activities for bringing a complaint of discrimination or harassment. UC ANR policy also prohibits retaliation against a person who assists someone with a complaint of discrimination or harassment, or participates in any manner in an investigation or resolution of a complaint of discrimination or harassment. Retaliation includes threats, intimidation, reprisals, and/or adverse actions related to any of its programs or activities.

UC ANR is an Equal Opportunity/Affirmative Action Employer. All qualified applicants will receive consideration for employment and/or participation in any of its programs or activities without regard to race, color, religion, sex, national origin, disability, age or protected veteran status.

University policy is intended to be consistent with the provisions of applicable State and Federal laws.

Inquiries regarding the University's equal employment opportunity policies may be directed to: Affirmative Action Compliance and Title IX Officer, University of California, Agriculture and Natural Resources, 2801 Second Street, Davis, CA 95618, (530) 750-1343. Email: titleixdiscrimination@ ucanr.edu. Website: https://ucanr.edu/sites/anrstaff/Diversity/ Affirmative_Action/.

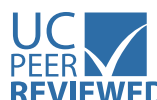

This publication has been anonymously peer reviewed for technical accuracy by University REVIEWED of California scientists and other qualified professionals. This review process was managed by UC ANR Associate Editor Susan D. Kocher. web-4/20-LC/SO

https://doi.org/10.3733/ucanr.8680 